\title{
On the Relationship of Biogenic Primary and Secondary Organic Aerosol Tracer Compounds on the Aethalometer Model Parameters
}

\author{
Johan Martinsson ${ }^{*}$, Moa K. Sporre², Guillaume Pédehontaa-Hiaa1, Hafiz Abdul Azeem³ \\ ${ }^{1}$ Medical Radiation Physics, Department of Translational Medicine, Lund University, Box 118, SE-22100, Malmö, \\ Sweden \\ ${ }^{2}$ Division of Nuclear Physics, Lund University, Box 118, SE-22100, Lund Sweden \\ ${ }^{3}$ Centre for Analysis and Synthesis, Department of Chemistry, Lund University, Box 118, SE-22100, Lund, Sweden
}

\begin{abstract}
The aethalometer model has shown to offer a fast, inexpensive and robust method for source apportionment. The method relies on aerosol light absorption attribution, mass balance of the total carbon and results in a fraction of unaccounted, residual carbon that has been associated to biogenic carbon due to its presumably non-light absorbing properties. This residual carbon and its relation to tracers of biogenic primary and secondary organic aerosol was investigated at a rural measurement station in Sweden. Special focus is devoted to 3-methyl-1,2,3-butanetricarboxylic acid (MBTCA), a secondgeneration oxidation compound in biogenic secondary organic aerosols. The results show that the residual carbon and the biogenic tracers show a high degree of correlation and that the tracers were highly seasonally dependent with largest carbon contributions during summer. MBTCA showed positive correlation with the aethalometer model derived absorption coefficients from fossil fuel carbonaceous aerosol, stressing the suspicion that biogenic aerosol might be falsely apportioned to fossil fuel carbon in the aethalometer model. MBTCA showed an increasing degree of correlation with higher aethalometer absorption coefficient wavelengths. However, spectrophotometric analysis revealed that the ambient concentrations of MBTCA are most likely to low to give a significant response in the aethalometer. These results support the application of MBTCA as a molecular tracer for biogenic secondary organic aerosol and indicates that a large fraction of the aethalometer model residual carbon is of biogenic origin. Future studies should investigate the light absorbing properties of precursor monoterpenes such as $\alpha$-pinene, their oxidation products and eventual influence on the aethalometer model.
\end{abstract}

Keywords: Aethalometer; Source apportionment; Biogenic aerosol.

\section{INTRODUCTION}

The carbonaceous aerosol contributes to approximately $20-50 \%$ to the total aerosol mass in Europe (Kanakidou et al., 2005; Putaud et al., 2010; Fuzzi et al., 2015). Its high abundance, detrimental health effects and climate impact makes the carbonaceous aerosol crucial to study as an environmental stressor. The ambient carbonaceous aerosol mainly originates from three distinguished sources: fossil fuel combustion, biomass burning and biogenic emissions (Liousse et al., 1996). Due to the detrimental effects of combustion generated aerosol particles, fossil fuel combustion and biomass burning aerosol physicochemical properties and related source apportionment have gained large attention in the past (Barregard et al., 2006; Naeher et al., 2007; Bolling et al., 2009; Sehlstedt et al., 2010; Janssen et al., 2011;

\footnotetext{
* Corresponding author.

E-mail address: johan.martinsson@med.lu.se
}

Bond et al., 2013). However, there are only a few source apportionment studies focusing on the biogenic carbonaceous aerosol fraction (Yttri et al., 2011).

Biogenic aerosols are comprised of biogenic primary organic aerosols (BPOA) and biogenic secondary organic aerosols (BSOA). BPOA can be found as pollen, bacteria, fungal spores and plant debris. BSOA is the product of biogenic volatile organic compound (BVOC) oxidation in the atmosphere. BVOCs are used as communicative tool as well as to handle abiotic and biotic stress and is emitted globally in large quantities from terrestrial and aquatic plants (Gabric et al., 2001; Penuelas and Llusia, 2003; Sharkey et al., 2008; Monson et al., 2013; Glasius and Goldstein, 2016; Steinke et al., 2018). Emissions of BPOA and BVOCs have been shown to increase with increasing photosynthetically active radiation (PAR) and temperature (Guenther et al., 1993; Guenther et al., 1995; Hakola et al., 2003), which explains the dominance of the biogenic mass fraction in carbonaceous aerosol during summer (Gelencser et al., 2007; Genberg et al., 2011; Yttri et al., 2011; Martinsson et al., 2017a, b). The main BVOC is isoprene, which is emitted 
mostly from deciduous forests with an annual emission rate of 400-600 Tg y ${ }^{-1}$ (Laothawornkitkul et al., 2009). Coniferous forest emits large quantities $\left(30-500 \mathrm{Tg} \mathrm{y}^{-1}\right)$ of monoterpenes such as $\alpha$-pinene, $\beta$-pinene, $\Delta^{3}$-carene and limonene (Räisänen et al., 2008; Laothawornkitkul et al., 2009; Hakola et al., 2012). The $\alpha$-pinene contributes to approximately $40 \%$ of the global monoterpene emissions (Guenther et al., 2012). Landmasses at northern latitudes are largely covered by coniferous forests. Global climate modeling has shown that these areas are the most susceptible for global warming in terms of temperature increment (IPCC, 2013). Hence, following an increase in temperature may cause a significant increase in monoterpene emission at these latitudes (Sporre et al., 2019). Consequently, global BSOA production may increase due to increased BVOC emissions.

Andersson-Sköld and Simpson (2001) showed that monoterpene BSOA may contribute to $50 \%$ of the total organic aerosol mass over the Nordic countries with $\alpha$-pinene being the dominant precursor compound. Atmospheric oxidation of $\alpha$-pinene can result in the production of first-generation oxidation products including pinic acid, pinonic acid and pinonaldehyde (Larsen et al., 2001; Jaoui and Kamens, 2002; Lee et al., 2006). The 3-methyl-1,2,3-butanetricarboxylic acid (MBTCA) is produced by gas-phase oxidation of pinonic acid (Muller et al., 2012), and is thus a second-generation oxidation product from $\alpha$-pinene. MBTCA has been suggested and used as a tracer for BSOA originating from $\mathrm{OH}$-initiated oxidation of monoterpene emissions (Szmigielski et al., 2007; Zhang et al., 2010). MBTCA has low volatility (1.8 \pm $1.3 \cdot 10^{-3} \mu \mathrm{g} \mathrm{m}^{-3}$ ) and an atmospheric lifetime of 3-5 days assuming an daily average $\mathrm{OH}$ radical concentration of $10^{6}$ molecules $\mathrm{cm}^{-3}$ (Donahue et al., 2013; Kostenidou et al., 2018), and has been detected and measured in various terrestrial locations on Earth (Kubatova et al., 2000; Kubatova et al., 2002; Gao et al., 2006; Lewandowski et al., 2007; Kourtchev et al., 2008a, b; Fu et al., 2009; Kourtchev et al., 2009; Yasmeen et al., 2011; Vogel et al., 2013; Martinsson et al., 2017c). Recently, Kostenidou et al. (2018) presented a highresolution aerosol mass spectrometry (HR-AMS) spectra of MBTCA and suggested to use the $\mathrm{m} / \mathrm{z} 141$ as a signature for MBTCA in AMS measurements. Hence, MBTCA has great potential acting as a high time resolution tracer for BSOA emissions.

Source apportionment as a concept offers a basis for decision making in order to mitigate health and climate effects of carbonaceous aerosol. Low cost, low maintenance and high time resolution are desirable attributes of an auspicious source apportionment method. The aethalometer model, originally presented by Sandradewi et al. (2008a), utilizes differences in the spectral light absorption of fossil fuel combustion and wood burning aerosol to apportion the organic aerosol mass to these two sources. All non-light absorbing carbon present are, through mass balance of the total carbon apportioned as residual carbon, which is thought to contain large portions of the biogenic carbon as BSOA or BPOA. The aethalometer model has been proven to deliver a robust source apportionment with high time resolution to a low cost (Martinsson et al., 2017b). In a recent study by Martinsson et al. (2017b) it was shown that the wood burning parameter from the aethalometer model correlated satisfactory with the chemical tracer for wood burning, levoglucosan. This result can be viewed as a strong indicator of the method working correctly for wood burning apportionment. Hence, the aethalometer model combustion components, wood burning and fossil fuel combustion, has been evaluated against strong source indicators, tracers, such as levoglucosan and radiocarbon $\left({ }^{14} \mathrm{C}\right)$. BSOA compounds have been shown to have low or negligible light absorption due to absence of conjugated molecular systems (Nakayama et al., 2010; Henry and Donahue, 2012; Laskin et al., 2014). However, whether increased mass concentrations of non-light absorbing carbon have effect on filter based light absorption techniques for source apportionment purposes remains unexplored. In this study we want to investigate the aethalometer model and the presumably non-light absorbing residual carbon and its possible strong association to biogenic carbon through measurement of a biogenic tracers and in particular a tracer for monoterpene oxidation, MBTCA.

\section{METHODS}

\section{Measurement Site and Sampling}

Ambient aerosol sampling was conducted at the aerosol, clouds and trace gases research infrastructure (ACTRIS) and European Monitoring and Evaluation Programme (EMEP) Vavihill measurement station. Vavihill measurement station was located on a ridge at an altitude of 172 m.a.s.l. $\left(56^{\circ} 01^{\prime} \mathrm{N}\right.$, $\left.13^{\circ} 09^{\prime} \mathrm{E}\right)$ in southern Sweden. The surrounding landscape consists of mixed deciduous and coniferous forests. The measurement station itself was in the middle of a small pasture that is occasionally visited by grazing cattle from May to September. The cities closest to Vavihill are Helsingborg, Malmö and Copenhagen located at distances of 20, 50 and $65 \mathrm{~km}$, respectively, in the west, south-west direction. Aerosols were sampled through a $\mathrm{PM}_{10}$ inlet at $38 \mathrm{~L} \mathrm{~min}^{-1}$ on preheated $\left(900^{\circ} \mathrm{C}\right.$ for four hours) $47 \mathrm{~mm}$ quartz fiber filters (Pallflex 2500QAT-UP) during $72 \mathrm{~h}$ using an automatic low volume sampler (Leckel SEQ46/50). Active carbon denuders were installed in the sampling line together with double filters in order to correct for sampling artifacts caused by VOCs, the denuders were replaced once every year. Following sampling, the filters were placed in petri dishes, wrapped in aluminum foil and stored in a $-18^{\circ} \mathrm{C}$ freezer until analysis. Sampling was conducted continuously from 2007 until 2017. In this paper we used filters that were sampled during April 2013 to August $2013(\mathrm{~N}=47)$ and September 2015 to March $2016(\mathrm{~N}=61)$. The reason for two incoherent sampling periods was the purpose to cover all months in a year together with varying instrument availability and functioning during the operation of the measurement station. The Vavihill measurement station was decommissioned during 2018 and all measurement activity has been moved to the ACTRIS, EMEP and Integrated Carbon Observation System in Sweden (ICOS), Hyltemossa measurement station $20 \mathrm{~km}$ east of Vavihill.

\section{Thermo-optical Analysis}

Organic carbon (OC), elemental carbon (EC) and total 
carbon (TC) was derived from thermo-optical analysis of the filters using a DRI carbon analyzer (model 2001) with the EUSAAR_2 analytic protocol (Cavalli et al., 2010). The method utilizes the refractive properties of the carbonaceous aerosol to evolve and quantify the carbon at different temperatures in different atmospheres. In short, the EUSAAR_2 protocol initiate the analysis by allowing OC from a $0.5 \mathrm{~cm}^{2}$ filter to evolve in an inert $\mathrm{He}$-atmosphere to a maximum temperature of $570^{\circ} \mathrm{C}$. During the heating process a $633 \mathrm{~nm} \mathrm{He} / \mathrm{Ne}$ laser is continuously irradiating the filter, a photodetector is mounted $180^{\circ}$ from the laser light path to measure the light transmission through the filter. When the laser transmission signal reaches its baseline value the remaining carbon is defined to be EC. The EC is then heated from 500 to $850^{\circ} \mathrm{C}$ in a $2 \% \mathrm{O}_{2}$ atmosphere, allowing refractory carbon to be combusted. All carbon that are evolved from the filter are oxidized to $\mathrm{CO}_{2}$. The $\mathrm{CO}_{2}$ is further reduced to methane by passing hydrogen gas over a zinc catalyst. Finally, the methane is quantified using a flame ionization detector (FID). A recent study by Cavalli $e t$ al. (2016) estimated the thermo-optical analysis uncertainty of TC from Vavihill filter samples to $17 \%$ relative standard deviations (RSD).

\section{Light Absorption Measurements}

The light absorption of ambient aerosols was measured with an aethalometer (AE33, Magee Scientific). Aerosols were sampled with a flow of $5 \mathrm{~L} \mathrm{~min}^{-1}$ through a $\mathrm{PM}_{10}$ inlet to the aethalometer where the aerosol were deposited on a filter spot. The aethalometer filter spot is continuously irradiated by seven LEDs with wavelengths from $370 \mathrm{~nm}$ to $950 \mathrm{~nm}$. The light attenuation was measured with photodetectors with a time resolution of $1 \mathrm{~min}$. The aethalometer, model AE33, was developed to correct for the artefacts common in filter-based light absorption techniques, the shadowing effect and the filter matrix scattering effect (Drinovec et al., 2015). These artefacts are described in detailed by Weingartner et al. (2003).

The aethalometer output parameter is attenuation coefficients which, after automatic artefact corrections, are transformed to absorption coefficients for each wavelength, $b_{a b s}(\lambda)$, with the unit of $m^{-1}$. Further, the $b_{a b s}(\lambda)$ can be converted to mass concentration of $\mathrm{BC}\left(\mu \mathrm{g} \mathrm{m}^{-3}\right)$ by division of the specific mass absorption coefficients $\left(\sigma_{\text {abs }}(\lambda), \mathrm{MAC}\right)$, with the unit $\mathrm{m}^{2} \mathrm{~g}^{-1}$.

\section{The Aethalometer Model}

For the source apportionment of carbon mass the aethalometer model originally presented by Sandradewi et al. (2008a) with modifications by Martinsson et al. (2017b) was used. In the aethalometer model the total aerosol light absorption are attributed to light absorbing carbon from fossil fuel combustion (FF) or wood burning (WB) according to Eqs. (1)-(3):

$$
\begin{aligned}
& b_{a b s}(\lambda)=b_{a b s F F}(\lambda)+b_{a b s W B}(\lambda) \\
& \frac{b_{a b s F F}(370 \mathrm{~nm})}{b_{a b s F F}(950 \mathrm{~nm})}=\left(\frac{370}{950}\right)^{-A A E_{F F}}
\end{aligned}
$$

$\frac{b_{a b s W B}(370 \mathrm{~nm})}{b_{a b s W B}(950 \mathrm{~nm})}=\left(\frac{370}{950}\right)^{-A A E_{W \mathrm{~B}}}$

In these equations, the AAE is the absorption Angström exponent that describes the spectral absorption dependence of the source specific aerosols. These parameters need to be accurately pre-defined and this is commonly achieved by using reference values from laboratory or field experiments. In this study we used $\mathrm{AAE} \mathrm{WB}_{\mathrm{B}}=1.81$ and $\mathrm{AAE}_{\mathrm{FF}}=1.0$, values that were used and motivated in the study by Martinsson $e t$ al. (2017b). From the derived aethalometer model absorption coefficients, $b_{a b s F F}$ and $b_{a b s W B}$, it is now possible to calculate the source apportioned carbonaceous aerosol mass (CM). CM is thought to consist of three components, where $\mathrm{CM}_{\mathrm{FF}}$ and $\mathrm{CM}_{\mathrm{WB}}$ are the source apportioned carbon mass concentrations, and $\mathrm{CM}_{\mathrm{Bio}}$ is a residual non-light absorbing component:

$$
\begin{aligned}
& T C=C M_{F F}+C M_{W B}+C M_{B i o}=C_{1} \cdot b_{a b s F F}(950 \mathrm{~nm})+ \\
& C_{2} \cdot b_{a b s W B}(370 \mathrm{~nm})+C M_{B i o}
\end{aligned}
$$

In this study we want to compare the residual carbon, $\mathrm{CM}_{\text {Bio, }}$, to biogenic aerosol tracer compounds. Hence, solving Eq. (4) as a multilinear regression, leaving $\mathrm{CM}_{\mathrm{Bio}}$ as a fixed intercept as originally proposed by Sandradewi et al. (2008a) is not convenient when aiming to study potential variation in $\mathrm{CM}_{\mathrm{Bio}}$. Hence, we use the alternative solution where $\mathrm{CM}_{\mathrm{Bio}}$ is allowed to vary outside the Eqs. (5)-(6) that are used to calculate $\mathrm{C}_{1}$ and $\mathrm{C}_{2}$.

$$
\frac{T C}{b_{a b s W B}(370 \mathrm{~nm})}=C_{1} \frac{b_{a b s F F}(950 \mathrm{~nm})}{b_{a b s W B}(370 \mathrm{~nm})}+C_{2}+\frac{C M_{B i o}}{b_{a b s W B}(370 \mathrm{~nm})}
$$

$\frac{T C}{b_{a b s F F}(950 \mathrm{~nm})}=C_{2} \frac{b_{a b s W B}(370 \mathrm{~nm})}{b_{a b s F F}(950 \mathrm{~nm})}+C_{1}+\frac{C M_{B i o}}{b_{a b s F F}(950 \mathrm{~nm})}$

$\mathrm{C}_{1}$ and $\mathrm{C}_{2}$ can be calculated as the slope of the linear regression of Eqs. (5)-(6) as in Martinsson et al. (2017b). The calculations for deriving $\mathrm{C}_{1}$ and $\mathrm{C}_{2}$ are made exclusively for samples collected during winter (December-February), in this way the presumed non-light absorbing biogenic carbon $\left(\mathrm{CM}_{\mathrm{Bio}}\right)$ are minimized as a factor of interference. As opposed to Sandradewi et al. (2008), $\mathrm{CM}_{\mathrm{Bio}}$ is here allowed to vary outside the linear regressions:

$$
C M_{B i o}=T C-C M_{F F}-C M_{W B}
$$

The linear slopes representing $\mathrm{C}_{1}$ and $\mathrm{C}_{2}$ was estimated to 446853 and $96272 \mu \mathrm{g} \mathrm{m}^{-2}$, respectively, based on 30 data points obtained during the winter (December-February). The coefficient of determination, $\mathrm{R}^{2}$, was 0.39 for the $\mathrm{C}_{1}$ parameter and 0.31 for the $C_{2}$ parameter, these numbers are in similar range to the parameter statistics found in Martinsson et al. (2017b). Further, since $\mathrm{CM}_{\text {Bio }}$ is expected to be suppressed during winter, the last division term in Eqs. (5)-(6) should result in a small number relative to the estimated $C$ parameters. 
Hence, the intercept of the linear fit of Eq. (5) (i.e., $\mathrm{C}_{2}+$ $\mathrm{CM}_{\mathrm{Bio}} / \mathrm{b}_{\mathrm{absWB}(370 \mathrm{~nm})}$ ) should be very close to the estimated $\mathrm{C}_{2}$ parameter through the linear fit of Eq. (6). The same concept is applicable for quality control of the $C_{1}$ parameter. The intercept of the linear regression of Eq. (5) was estimated to 82571 which is deviating by $14 \%$ to the estimated $\mathrm{C}_{2}$ parameter. The intercept of the linear regression of Eq. (6) was estimated to 396936 which is deviating by $11 \%$ to the estimated $\mathrm{C}_{1}$ parameter. These deviations are smaller than the ones estimated in Martinsson et al. (2017b) who found deviations of 22 and $15 \%$ of the $C_{1}$ and $C_{2}$ parameters to their intercepts, respectively. The linear regressions plots are displayed in Figs. S1 and S2 in the supplement.

As mentioned earlier it is also possible to solve Eq. (4) as a multilinear regression as originally proposed by Sandradewi et al. (2008a). However, in such case the $\mathrm{CM}_{\text {Bio }}$ would be fixed as a residual as a constant and not be allowed to vary in time. Further, this was examined in Martinsson et al. (2017b) and gave unrealistic high $\mathrm{C}_{1}$ parameter. Hence, for the purpose of this study the originally proposed solution to Eq. (4) will not be considered here.

\section{Analysis of Biogenic Aerosol Tracers}

Analysis of six emission markers including levoglucosan, arabitol, fructose, sucrose, cis-pinonic acid and 3-methyl1,2,3-butane tricarboxylic acid was performed according to the method of Pietrogrande et al. (2014). Briefly, filter punches were divided into small pieces using a sterile surgical blade. Extractions were performed in ultrasonic bath for $15 \mathrm{~min}$ using $10 \mathrm{~mL}$ of methanol and dichloromethane mixture $(9: 1)$. Extracts were filtered prior to analysis using a $25 \mathrm{~mm}$ (pore size $0.45 \mu \mathrm{m}$ ) polypropylene syringe filter.

Extracts were analyzed by supercritical fluid chromatography (SFC, Agilent 1260 Infinity II) coupled to Triple Quadrupole Mass Spectrometer (Agilent 6460 system) using the following conditions. Initially a mobile phase $\left(\mathrm{CO}_{2} /\right.$ methanol) with composition of $93: 7 \%$ was used for $5 \mathrm{~min}$ followed by a composition of $80: 20 \%$ for $6.5 \mathrm{~min}$ and returning back to $93: 7 \%$ at 7.5 minutes. Mobile phase and make-up (methanol) flow rates were maintained at $2.5 \mathrm{~mL}$ and $0.5 \mathrm{~mL}$, respectively. Injection volume of $2 \mu \mathrm{L}$ was used for all samples while column temperature was maintained at $50^{\circ} \mathrm{C}$. The back-pressure regulator was programmed for 135 bars and $50^{\circ} \mathrm{C}$ throughout the analysis. Mass spectrometric analysis was performed using gas temperature of $80^{\circ} \mathrm{C}$, gas flow of $20 \mathrm{~L} \mathrm{~min}^{-1}$ and nebulizer pressure of $30 \mathrm{psi}$. Sheath gas temperature and flow were $250^{\circ} \mathrm{C}$ and $12 \mathrm{~L} \mathrm{~min}^{-1}$, respectively. Capillary and nozzle voltages were set to $3000 \mathrm{~V}$ and $1000 \mathrm{~V}$, respectively, whereas an electron multiplier voltage of $400 \mathrm{~V}$ was used. Identification and quantification of emission markers was performed using retention times and SIM using $\mathrm{m} / \mathrm{z} 161,151,179,341,183,203$ for levoglucosan, arabitol, fructose, sucrose, cis-pinonic acid and 3-methyl-1,2,3-butane tricarboxylic acid, respectively.

\section{Spectrophotometric Analysis}

A standard of 3-methyl-1,2,3-butane tricarboxylic acid (MBTCA) was purchased from Toronto Research Chemicals Inc., Toronto, Canada. Five $25 \mathrm{~mL}$ solutions of 10, 20, 100,
250 and $500 \mathrm{mmol} \mathrm{L}^{-1}$ was produced by dissolving weighed MBTCA powder in ultrapure water (MilliQ). Spectrophotometric analyses were carried out using a portable spectrophotometer (USB-650, Red Tide Spectrometer, OceanOptics) using a wavelength range of 200-850 nm. $2 \mathrm{~mL}$ of ultrapure water was placed in a quartz cuvette and used as background measurement. The cuvette was then rinsed with ultrapure water before adding any MBTCA solution. Output data from the spectrophotometer was absorbance (A). Absorbance was then transformed to absorption per density $\left(\alpha \rho^{-1}\right)$ according to Chen and Bond (2010):

$\alpha \rho^{-1}=\frac{A}{c \cdot L} \cdot \ln (10)$

$\mathrm{L}$ is the optical path length, which in this case was $1 \mathrm{~cm}$ and $\mathrm{c}$ is the concentration of the MBTCA solutions expressed as mass per volume.

\section{Trajectory Analysis}

The Hybrid Single Particle Lagrangian Integrated Trajectory Model (HYSPLIT) (Draxier and Hess, 1998; Stein et al., 2015) was used to study the history of the air mass carrying the particles sampled on the filters and measured by the aethalometer. Gridded meteorological data from the Centre of Environmental Predictions (NCEP) Global Data Assimilation System (GDAS) were used as input to trajectory model. Back-trajectories were calculated at an hourly frequency $120 \mathrm{~h}$ backward in time and the trajectories started $100 \mathrm{~m}$ above ground at the Vavihill measurement site. For each filter sample, 72 trajectories were used since the sampling time was $72 \mathrm{~h}$. Four regions of origin were defined (Northeast $=0-90^{\circ}$; Southeast $=90-180^{\circ} ;$ Southwest $=180-270^{\circ} ;$ Northwest $=$ $270-360^{\circ}$ ) and for each sample the fraction of time that the airmass spent over each of the regions of origin was calculated.

\section{Meteorological Observations}

Temperature and precipitation data were obtained through the website of the Swedish Meteorological and Hydrological Institute (SMHI). The closest observation points for temperature and precipitation to the Vavihill measurement station was found in the city of Helsingborg $\left(56^{\circ} 03^{\prime} \mathrm{N}\right.$, $\left.12^{\circ} 77^{\prime} \mathrm{E}\right)$ and Gillastig $\left(56^{\circ} 01^{\prime} \mathrm{N}, 13^{\circ} 23^{\prime} \mathrm{E}\right)$, respectively. Helsingborg is located $20 \mathrm{~km}$ west of Vavihill while Gillastig is located $3 \mathrm{~km}$ southeast of Vavihill.

\section{RESULTS AND DISCUSSION}

\section{Temporal Variation of Measured Parameters}

Fig. 1(a) shows the temporal variations of OC and EC for the measurement period. Spring and summer showed similar concentrations levels for $\mathrm{OC}\left(\mathrm{OC}_{\text {meanspring }}=1.17 \mu \mathrm{g} \mathrm{m}^{-3}\right.$; $\left.\mathrm{OC}_{\text {meanSummer }}=1.28 \mu \mathrm{g} \mathrm{m}^{-3}\right)$ and $\mathrm{EC}\left(\mathrm{EC}_{\text {meanSpring }}=0.20 \mu \mathrm{g} \mathrm{m}^{-3}\right.$; $\left.\mathrm{EC}_{\text {meanSummer }}=0.15 \mu \mathrm{g} \mathrm{m}^{-3}\right)$. Both $\mathrm{OC}$ and $\mathrm{EC}$ were elevated in the autumn $\left(\mathrm{OC}_{\text {mean }}=1.68 \mu \mathrm{g} \mathrm{m}^{-3} ; \mathrm{EC}_{\text {meanAutumn }}=0.38 \mu \mathrm{g} \mathrm{m}^{-3}\right)$ which is mainly caused by the two peaks during 2015-10-18 and 2015-11-02, these two periods had slightly lower temperature $\left(7.9\right.$ and $\left.8.8^{\circ} \mathrm{C}\right)$ than the average temperature of 
the whole autumn $\left(\mathrm{T}_{\text {meanAutumn }}=9.3^{\circ} \mathrm{C}\right)$. Hence, it can be expected that the higher carbonaceous aerosol concentrations during these periods was caused by and increased activity of residential wood burning. As expected, the levoglucosan concentrations was also elevated during these periods ( 0.35 and $0.25 \mu \mathrm{g} \mathrm{m}^{-3}$ compared to the autumn mean of $0.08 \mu \mathrm{g} \mathrm{m}^{-3}$ ). Winter data display $\mathrm{OC}_{\text {meanWinter }}$ and $\mathrm{EC}_{\text {meanWinter }}$ of 0.96 and $0.21 \mu \mathrm{g} \mathrm{m}^{-3}$, respectively. As observed during the autumn, suppressed temperature during 2016-01-04 and 2016-01-13 $\left(-3.2\right.$ and $\left.0.0^{\circ} \mathrm{C} ; \mathrm{T}_{\text {meanWinter }}=2.3^{\circ} \mathrm{C}\right)$ resulted in two distinct peaks in $\mathrm{OC}$ and $\mathrm{EC}$ and was associated with increased levoglucosan concentrations $\left(0.15\right.$ and $0.15 \mu \mathrm{g} \mathrm{m}^{-3}$ compared to winter mean of $0.10 \mu \mathrm{g} \mathrm{m}^{-3}$ ) and also increased AAE
(1.58 and 1.52 compared to winter mean of 1.39, Fig. 1(b)). The transition from the 2013 to the 2015-2016 measurement period did not result in any abrupt and significant change in the carbonaceous aerosol concentration.

The absorption Ångström exponent (AAE) experience low levels during the spring and summer of 2013 and rapidly increases with the transition to the 2015 and 2016 measurement period. The increase from summer to autumn and winter is expected due to increased wood burning as the temperature decreases, however this rapid shift in AAE could be worth investigating more in depth. This transition is actually followed by a rather steep decrease in ambient temperature, from a quite stable summer temperature during

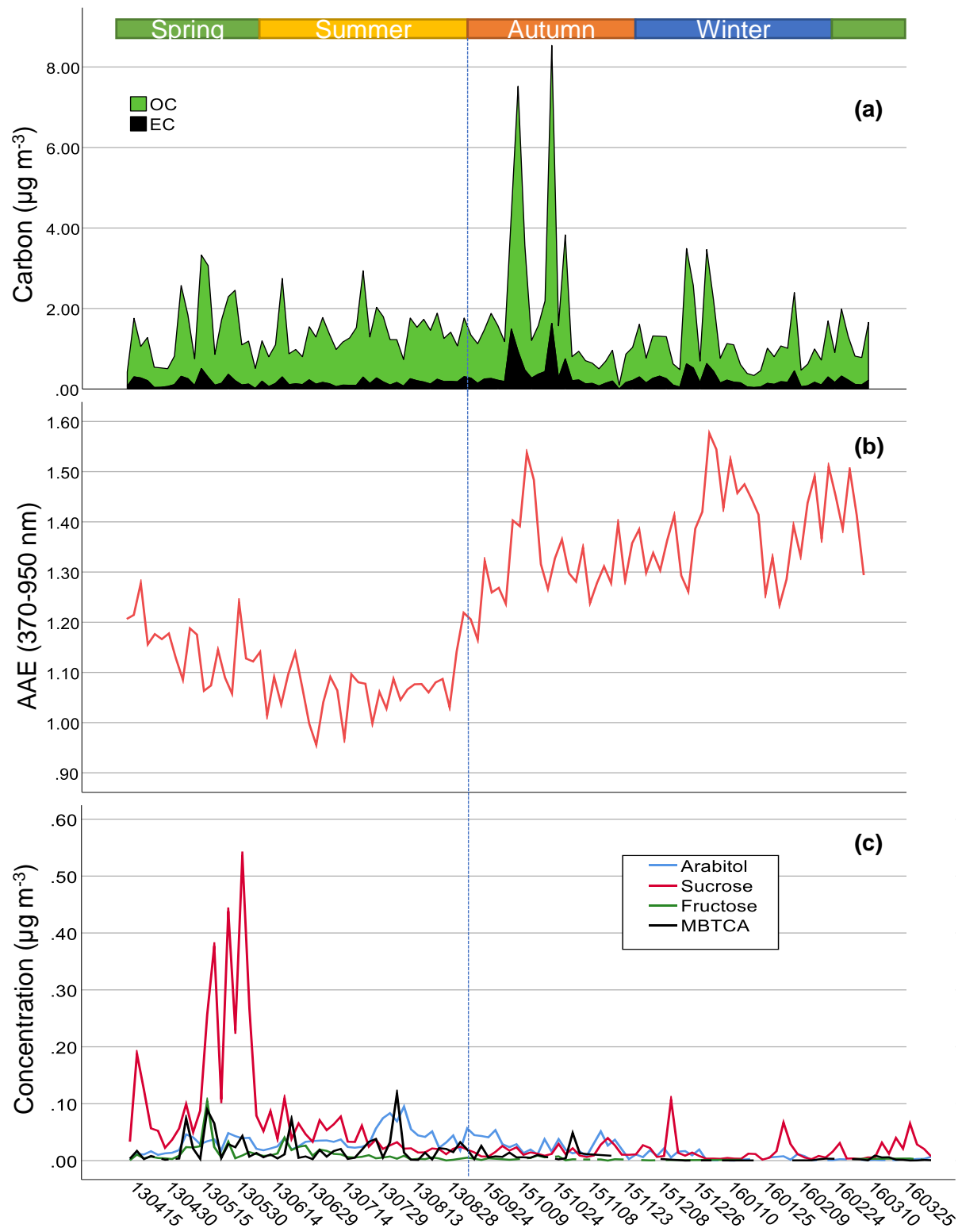

Fig. 1. (a) OC and EC during the measurement period. The dotted line in the transition between summer and autumn displays the junction between the measurement period of 2013 and 2015-2016. $\mathrm{N}=111$. (b) Temporal variation of the absorption Ångström exponent (AAE) during the measurement period. The AAE was calculated by a linear fit using absorption coefficient in all seven available wavelengths $(370-950 \mathrm{~nm}) . \mathrm{N}=106$. (c) Temporal variation of the measured biogenic tracer compounds. $\mathrm{N}_{\text {Arabitol }}=103 ; \mathrm{N}_{\text {Sucrose }}=115 ; \mathrm{N}_{\text {Fructose }}=72 ; \mathrm{N}_{\mathrm{MBTCA}}=81$. 
2013 with a mean and standard deviation of $16.9 \pm 2.1^{\circ} \mathrm{C}$ to around $7^{\circ} \mathrm{C}$ within a month (i.e., from $2015-09-12$ to 2015 10-12), presumably leading to a rapid increase in residential wood combustion. During this month of rapidly increasing AAE we can also see a fivefold increase in levoglucosan concentrations (i.e., from 0.01 to $0.05 \mu \mathrm{g} \mathrm{m}^{-3}$ ). Hence, the steep increase in AAE during the transition between measurement periods can be explained by decreasing temperatures and increased wood burning rather than any operational changes within the aethalometer instrument. The overall trend is although clear with low values during the cold season and the opposite during summer. AAE and temperature display a strong relationship $\left(\mathrm{R}^{2}=0.76\right)$. The seasonal AAE values is comparable to the levels found in Martinsson et al. (2017b).

Temporal variations of measured biogenic tracers are displayed in Fig. 1(c) and in Table 1. The concentrations of all tracers are, as expected, elevated during summer and suppressed during winter. MBTCA was during spring and summer on similar concentration levels to what has been found in previous European studies (Kourtchev et al., 2009; Kristensen and Glasius, 2011; Maenhaut et al., 2017; Martinsson et al., 2017c). Elevated MBTCA concentrations was further associated to raising temperatures $\left(\mathrm{R}^{2}=0.23, \mathrm{p}\right.$ $<0.01)$, an effect that was peculiarly prominent during spring $\left(\mathrm{R}^{2}=0.56, \mathrm{p}<0.01\right)$ and summer $\left(\mathrm{R}^{2}=0.27, \mathrm{p}<\right.$ $0.01)$. MBTCA showed a positive, although weak, wholeyear correlation to air masses from southeast $\left(\mathrm{R}^{2}=0.09, \mathrm{p}=\right.$ $0.03)$. The correlation was stronger during spring and summer $\left(\mathrm{R}^{2}=0.20, \mathrm{p}=0.04 ; \mathrm{R}^{2}=0.35, \mathrm{p}<0.01\right)$. The remaining air mass directions (NW, NE and SW) had a negative impact on the MBTCA concentration, this was particularly pronounced for air masses arriving from the northwestern sector $\left(\mathrm{R}^{2}=\right.$ $0.08, \mathrm{p}<0.01)$, a sector dominated by the North Sea and Atlantic Ocean. Arabitol, a tracer of fungal spores, hence primary biogenic organic aerosol (Bauer et al., 2008), was in a comparable concentration range $\left(\right.$ Arabitol $_{\text {meanSummer }}=$
$39.5 \mathrm{ng} \mathrm{m}^{-3}$ ) as found in Yttri et al. (2011) who measured biogenic tracers at four Scandinavian measurement stations during summer, Vavihill included. As MBTCA, arabitol also showed a strong positive temperature dependence $\left(\mathrm{R}^{2}=\right.$ 0.54 ), with a maximum concentration around $18-21^{\circ} \mathrm{C}$ which is a pattern that also have been observed by others (Burshtein et al., 2011). Arabitol showed no trends of variability with different air mass origins. Sucrose is a tracer of mainly pollen, but also soil biota and lichens (Caseiro et al., 2007; Yttri et al., 2007), and were highest during spring and summer. Pollen emissions by plants usually peaks in the beginning of the annual vegetation cycle (Siljamo et al., 2008; Yli-Panula et al., 2009; Manninen et al., 2014) which may be the explanation for finding the seasonal maximum of sucrose during spring, a phenomenon already observed by Yttri et al. (2007). Fructose found in aerosol can originate from the fruits of terrestrial plants but is also a tracer of pollen and vascular plant debris (Cowie and Hedges, 1984; Speranza et al., 1997). The fructose concentration followed similar temporal pattern as sucrose but was a factor 5-15 lower, similar observations has been made by others (Yttri et al., 2007; Verma et al., 2018). Both sucrose and fructose showed weak relationships to temperature $\left(R^{2}=0.11\right.$, for both), although analyzing the seasonal temperature correlation displayed stronger relationship during spring $\left(R^{2}=0.55\right.$ for sucrose; $\mathrm{R}^{2}=0.60$ for fructose) underlining the importance of the springtime pollen bursts. Further, both sugars showed no correlation with any air mass origin.

\section{Source Apportionment by the Aethalometer Model}

The temporal behavior of the aethalometer model output parameters is showed in Fig. 2(a). The carbon concentration reflects the carbonaceous content, as displayed in Fig. 1(a), while the distribution between the sources reflects the AAE and the aethalometer model. $\mathrm{CM}_{\mathrm{FF}}$ show low variation in mass concentration throughout the year (mean $=0.86 \pm$

Table 1. Seasonal means and standard deviations of the main measured and calculated parameters as well as meteorological data on temperature and precipitation.

\begin{tabular}{|c|c|c|c|c|}
\hline & Winter & Spring & Summer & Autumn \\
\hline $\mathrm{TC}\left(\mu \mathrm{g} \mathrm{m}^{-3}\right)$ & $1.17 \pm 0.87$ & $1.36 \pm 0.80$ & $1.42 \pm 0.56$ & $2.06 \pm 2.00$ \\
\hline $\mathrm{OC}\left(\mu \mathrm{g} \mathrm{m}^{-3}\right)$ & $0.96 \pm 0.70$ & $1.17 \pm 0.70$ & $1.28 \pm 0.50$ & $1.68 \pm 1.66$ \\
\hline $\mathrm{EC}\left(\mu \mathrm{g} \mathrm{m}^{-3}\right)$ & $0.21 \pm 0.17$ & $0.20 \pm 0.12$ & $0.15 \pm 0.07$ & $0.38 \pm 0.39$ \\
\hline AAE & $1.39 \pm 0.09$ & $1.20 \pm 0.12$ & $1.07 \pm 0.06$ & $1.31 \pm 0.09$ \\
\hline Levoglucosan $\left(\mathrm{ng} \mathrm{m}^{-3}\right)$ & $104.76 \pm 58.66$ & $55.65 \pm 36.65$ & $13.19 \pm 7.07$ & $77.22 \pm 78.41$ \\
\hline MBTCA $\left(\mathrm{ng} \mathrm{m}^{-3}\right)$ & $1.03 \pm 1.31$ & $14.95 \pm 24.58$ & $19.00 \pm 23.84$ & $12.58 \pm 12.07$ \\
\hline Arabitol $\left(\mathrm{ng} \mathrm{m}^{-3}\right)$ & $7.77 \pm 6.96$ & $16.49 \pm 16.15$ & $39.52 \pm 19.27$ & $27.17 \pm 15.05$ \\
\hline Sucrose $\left(\mathrm{ng} \mathrm{m}^{-3}\right)$ & $15.84 \pm 21.90$ & $84.90 \pm 111.28$ & $65.52 \pm 99.34$ & $16.29 \pm 8.61$ \\
\hline Fructose $\left(\mathrm{ng} \mathrm{m}^{-3}\right)$ & $0.88 \pm 0.35$ & $16.06 \pm 24.14$ & $10.22 \pm 8.55$ & $3.29 \pm 2.28$ \\
\hline cis-Pinonic acid & $2.86 \pm 0.96$ & $4.18 \pm 3.28$ & $5.67 \pm 7.87$ & $3.52 \pm 2.64$ \\
\hline $\mathrm{CM}_{\mathrm{FF}}\left(\mu \mathrm{g} \mathrm{m}^{-3}\right)$ & $0.68 \pm 0.42$ & $0.97 \pm 0.57$ & $0.81 \pm 0.31$ & $1.02 \pm 0.85$ \\
\hline $\mathrm{CM}_{\mathrm{WB}}\left(\mu \mathrm{g} \mathrm{m}^{-3}\right)$ & $0.64 \pm 0.73$ & $0.23 \pm 0.21$ & $0.05 \pm 0.05$ & $0.62 \pm 0.76$ \\
\hline $\mathrm{CM}_{\text {Bio }}\left(\mu \mathrm{g} \mathrm{m}^{-3}\right)$ & $-0.14 \pm 0.55$ & $0.17 \pm 0.81$ & $0.56 \pm 0.46$ & $0.43 \pm 0.92$ \\
\hline $\mathrm{CM}_{\mathrm{FF}(\mathrm{Mod})}\left(\mu \mathrm{g} \mathrm{m}^{-3}\right)$ & $0.25 \pm 0.15$ & $0.36 \pm 0.21$ & $0.30 \pm 0.11$ & $0.38 \pm 0.31$ \\
\hline $\mathrm{CM}_{\mathrm{WB}(\mathrm{Mod})}\left(\mu \mathrm{g} \mathrm{m}^{-3}\right)$ & $0.70 \pm 0.80$ & $0.26 \pm 0.23$ & $0.05 \pm 0.06$ & $0.66 \pm 0.83$ \\
\hline $\mathrm{CM}_{\text {Bio(Mod) }}\left(\mu \mathrm{g} \mathrm{m}^{-3}\right)$ & $0.22 \pm 0.47$ & $0.76 \pm 0.85$ & $1.08 \pm 0.50$ & $1.03 \pm 1.09$ \\
\hline Temperature $\left({ }^{\circ} \mathrm{C}\right)$ & $2.28 \pm 4.32$ & $7.98 \pm 4.93$ & $16.89 \pm 2.07$ & $9.27 \pm 3.49$ \\
\hline Precipitation (mm) & $3.28 \pm 3.33$ & $1.19 \pm 1.64$ & $1.88 \pm 2.69$ & $3.03 \pm 3.60$ \\
\hline
\end{tabular}




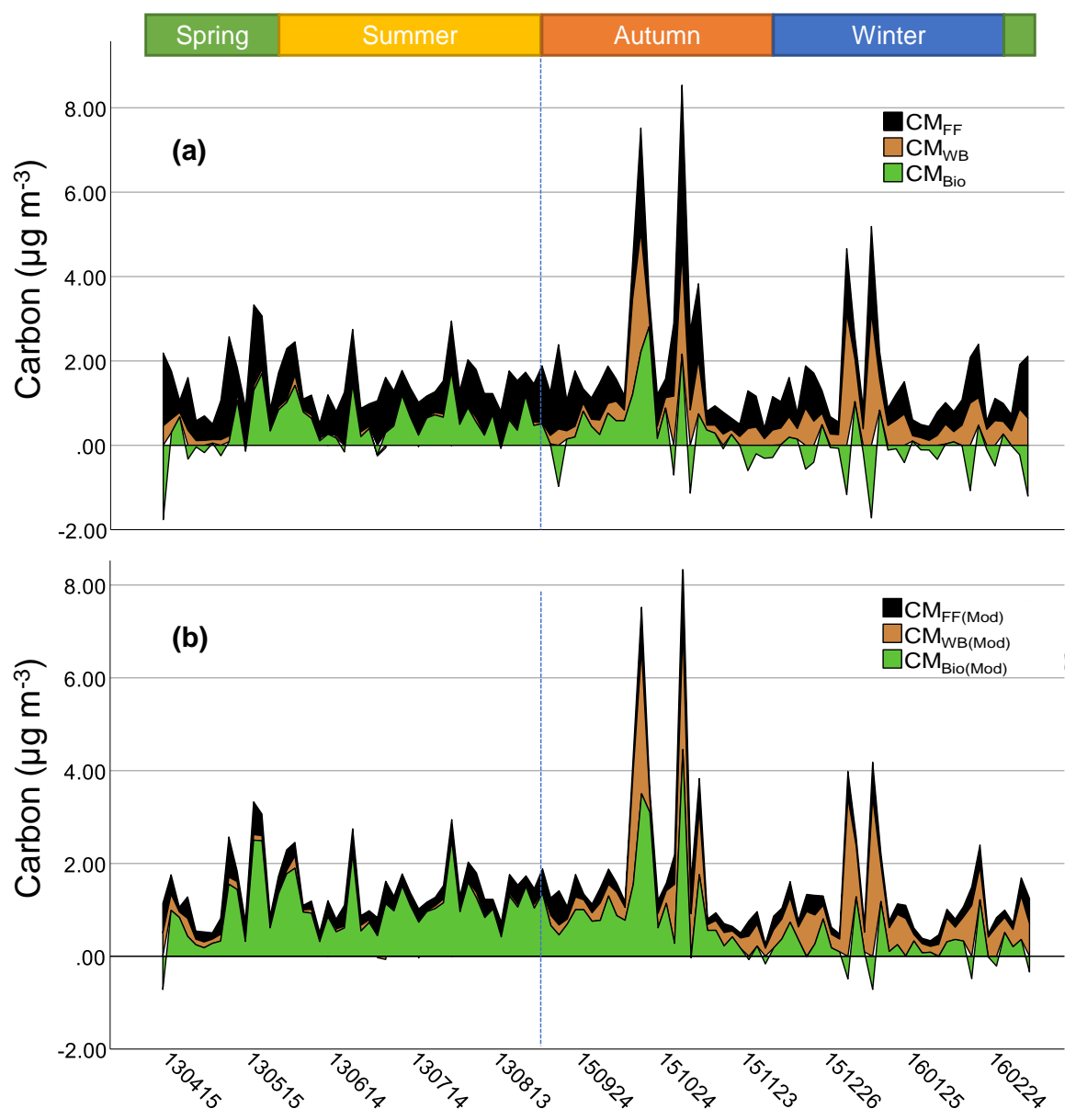

Fig. 2. (a) The originally calculated CM-parameters using the aethalometer model $\left(\mathrm{C}_{1}=446853 \mu \mathrm{g} \mathrm{m}^{-2} ; \mathrm{C}_{2}=96272 \mu \mathrm{g} \mathrm{m} \mathrm{m}^{-2}\right)$. (b) Modified and optimized CM-parameters $\left(\mathrm{C}_{1}=164974 \mu \mathrm{g} \mathrm{m}^{-2} ; \mathrm{C}_{2}=105076 \mu \mathrm{g} \mathrm{m}^{-2}\right)$. The dotted line in the transition between summer and autumn displays the transition between the measurement period of 2013 and $2015-2016$. $\mathrm{N}=106$.

$0.57 \mu \mathrm{g} \mathrm{m}^{-3}$ ), contributing in average with $68 \%$ to the $\mathrm{TC}$ mass concentration. This is a factor 2.4 higher than the contribution to TC found at Vavihill in Martinsson et al. $(2017 b)$ (mean contribution $=28 \%$ ) and could be an indicator of an erroneous $\mathrm{C}_{1}$ parameter. $\mathrm{CM}_{\mathrm{WB}}$ show a distinct seasonal pattern with elevated concentrations during winter $($ mean $=$ $0.64 \pm 0.73 \mu \mathrm{g} \mathrm{m}^{-3}$ ) compared to summer (mean $=0.05 \pm$ $0.05 \mu \mathrm{g} \mathrm{m}^{-3}$ ). The $\mathrm{CM}_{\mathrm{WB}}$ contribution to $\mathrm{TC}$ was maximized during winter with $55 \%$, this number is in line with previous findings from Vavihill (Martinsson et al., 2017b). $\mathrm{CM}_{\text {Bio }}$ peaked during summer with a mean mass concentration of $0.57 \pm 0.46 \mu \mathrm{g} \mathrm{m}^{-3}$, leading to a TC contribution of $35 \%$. The carbon contribution of $\mathrm{CM}_{\mathrm{Bio}}$ to $\mathrm{TC}$ is here a factor two lower than the value found in Martinsson et al. (2017b). Due to the aethalometer model setup in Eq. (7) it is possible for $\mathrm{CM}_{\mathrm{Bio}}$ to adopt negative values if the sum of $\mathrm{CM}_{\mathrm{FF}}$ and $\mathrm{CM}_{\mathrm{WB}}$ exceeds TC. Negative values of $\mathrm{CM}_{\mathrm{Bio}}$ was frequently observed during winter, thus leading to a winter average mass concentration of $-0.14 \pm 0.55 \mu \mathrm{g} \mathrm{m}^{-3}$. It can be feasible to allow some exceedances by the sum of $\mathrm{CM}_{\mathrm{FF}}$ and $\mathrm{CM}_{\mathrm{WB}}$ to the $\mathrm{TC}$ concentration, leading to negative $\mathrm{CM}_{\mathrm{Bio}}$ values. However, with the current estimated $\mathrm{C}$-parameters there are cases where $\mathrm{CM}_{\mathrm{FF}}$ and $\mathrm{CM}_{\mathrm{WB}}$ are in the range of 2-4 times higher than TC, which obstruct any endeavor to accomplish a sound source apportionment. It is indeed a non-trivial task to explain the highly elevated $C_{1}$ parameter found in this study. By studying the linear regression that was used to obtain the $C_{1}$ parameter (Fig. S1), it is evident that there are no clear outliers that could explain the elevated slope of the regression line. Hence, from a statistical point of view, it seems like the slope is correct, and that the issue is instead systematic. Another bias might occur when organic aerosol coats a soot core and hence increases the MAC value of the aerosol (Bond and Bergstrom, 2006). This means higher aerosol light absorption per unit mass. If there would be a high extent of organic coating (i.e., high MAC) during the $\mathrm{C}$ parameter calibration period (winter) lower $\mathrm{C}$ parameters would be obtained, compared to higher $\mathrm{C}$ parameters which would be the case if only fresh soot were detected (i.e., lower MAC). If the coating (or MAC value) during the measurement period will differ greatly from the mean MAC value during the calibration period a bias will be introduced which then might lead to over- or underestimation of either parameter $\left(\mathrm{CM}_{\mathrm{FF}}, \mathrm{CM}_{\mathrm{WB}}\right.$ or $\left.\mathrm{CM}_{\mathrm{Bio}}\right)$.

\section{Sensitivity Analysis and Optimization of $C_{1}$ and $C_{2}$ Parameters}

Unrealistically high $\mathrm{C}_{1}$ parameter results in an unrealistic 
apportionment of carbon to fossil sources. In this case, the $\mathrm{C}_{1}$ parameter is that high that it generates $\mathrm{CM}_{\mathrm{FF}}$ values which exceeds TC during 14 occasions. $\mathrm{CM}_{\mathrm{WB}}$ contribution to TC is similar to what was found in Martinsson et al. (2017b), however the sum of unrealistically high $\mathrm{CM}_{\mathrm{FF}}$ and realistic $\mathrm{CM}_{\mathrm{WB}}$ still creates a large deficit in $\mathrm{CM}_{\mathrm{Bio}}$. Hence, the $\mathrm{C}_{1}$ parameter, and consequently the $\mathrm{CM}_{\mathrm{FF}}$, needs to be adjusted to lower values in order to proceed with the analysis. Hence, we performed a sensitivity analysis in order to optimize the selection of C-parameters.

Averaging the C-parameters from this study with the respective values from Martinsson et al. (2017b) seems rational since the studies are conducted at the same measurement site, under similar circumstances and the performed measurements were conducted close in time to each other (i.e., 2013 and 2015-2016 vs. 2014-2015). Hence, combining the estimated $\mathrm{C}_{1}$ parameter from this study with the $\mathrm{C}_{1}$ parameter from Martinsson et al. (2017b) to a mean value will only decrease the $\mathrm{C}_{1}$ parameter from $446853 \mu \mathrm{g} \mathrm{m}^{-2}$ to $330660 \mu \mathrm{g} \mathrm{m}^{-2}$, i.e., a decrease by $26 \%$. Another possibility is to use the $C_{1}$ parameter found in Martinsson et al. (2017b), $214467 \mu \mathrm{g} \mathrm{m}^{-2}$. This procedure would result in a decrease of the $\mathrm{C}_{1}$ parameter by $52 \%$. However, the validity of this value is still challenged by the results presented in Martinsson et al. (2017b) who found that the aethalometer model apportioned fossil fuel carbonaceous aerosol was a factor 1.3 higher than fossil fuel carbon apportioned by radiocarbon and levoglucosan. Hence, as a final step, we embrace the results from Martinsson $e$ al. (2017b) and divide the $C_{1}$ parameter with a factor of 1.3 and get a final value of the $C_{1}$ parameter of $164974 \mu \mathrm{g} \mathrm{m}^{-2}$.

Since the contribution of $\mathrm{CM}_{\mathrm{WB}}$ to $\mathrm{TC}$ is similar to the study by Martinsson et al. (2017b), we will only fine-tune the $\mathrm{C}_{2}$ parameter by using the average from the current study and from Martinsson et al. (2017b). The averaged $\mathrm{C}_{2}$ parameter is $105076 \mu_{\mathrm{g} \mathrm{m}}^{-2}$, which is only $9 \%$ higher than the original value estimated in this study $\left(C_{2}=96272 \mu \mathrm{g} \mathrm{m}^{-2}\right)$, hence leading to small differences in the apportionment of wood burning carbonaceous aerosol.

It should be noted that using $\mathrm{C}$ parameters from other studies during different time periods might, even if the measurement location is constant, introduce bias into the source apportionment. However, with the more comparable results to previous conducted studies where radiocarbon and levoglucosan were used in the source apportionment it is likely that this methodology makes the source apportionment more realistic. Ideally, one should use high time resolved measurements (i.e., aerosol mass spectrometer and aethalometer measurements) during several winters in order to estimate more robust $\mathrm{C}$ parameters.

With the new C-parameters $\left(C_{1}=164974 \mu \mathrm{g} \mathrm{m}^{-2} ; C_{2}=\right.$ $105076 \mu \mathrm{g} \mathrm{m}^{-2}$ ) in place it is possible to evaluate the improvement of the apportionment through comparisons and correlations with source specific tracer compounds. The modified apportionment parameters are denoted $\mathrm{CM}_{\mathrm{FF}(\mathrm{Mod})}$, $\mathrm{CM}_{\mathrm{WB}(\mathrm{Mod})}$ and $\mathrm{CM}_{\mathrm{Bio}(\mathrm{Mod}) \text {. A quick comparison of the source }}$ contributions from this study to the study by Martinsson et al. (2017b) show a clear improvement. The $\mathrm{CM}_{\mathrm{FF}(\mathrm{Mod})}$ is now contributing with $25 \%$ to TC over the measurement period which is in line with Martinsson et al. (2017b) who found
$\mathrm{CM}_{\mathrm{FF}}$ to be in the range of $21-35 \%$. In this range we find the $\mathrm{CM}_{\mathrm{FF}(\mathrm{Mod})}$ in the lower end due to the use of the 1.3 factor as explained above. $\mathrm{CM}_{\mathrm{WB}(\mathrm{Mod})}$ show agreement with the contribution levels found in Martinsson et al. (2017b), with low contribution during summer (4\% to reference of $6 \%$ ) and high contributions during winter $(60 \%$ to reference of $57 \%)$. Further, $\mathrm{CM}_{\mathrm{WB}(\mathrm{Mod})}$ shows a significant correlation with levoglucosan (Fig. 3, $\mathrm{R}^{2}=0.462$, p $<0.01$ ), with a slightly higher coefficient of determination compared to the original $\mathrm{CM}_{\text {WB }}\left(\mathrm{R}^{2}=0.458\right)$. $\mathrm{CM}_{\text {Bio(Mod) }}$ shows excellent conformity in TC contribution when compared to Martinsson et al. (2017b) with high contribution in summer (74\% to reference of $72 \%$ ) and low during winter (14\% to reference of $8 \%$ ). The contribution during autumn (49\% to reference of $49 \%$ ) and spring ( $42 \%$ to $42 \%$ ) was on a significant level, as also showed in Martinsson et al. (2017b). Again, higher values of $\mathrm{CM}_{\mathrm{Bio}(\mathrm{Mod})}$ during summer and winter compared to the reference values obtained in Martinsson et al. (2017b) may depend on the 1.3 reduction factor of the $C_{1}$ parameter. $\mathrm{CM}_{\text {Bio }}$ displayed a rather poor correlation to MBTCA $\left(\mathrm{R}^{2}=\right.$ $0.14, \mathrm{p}<0.01)$, however this correlation was improved when comparing MBTCA to the modified apportioned biogenic carbon, $\mathrm{CM}_{\mathrm{Bio}(\mathrm{Mod})}\left(\mathrm{Fig} .4, \mathrm{R}^{2}=0.27, \mathrm{p}<0.01\right)$. The correlation was further slightly improved for arabitol $\left(R^{2}=0.13\right.$ vs. $R^{2}$ $=0.12)$ and for fructose $\left(R^{2}=0.06\right.$ vs. $\left.R^{2}=0.03\right)$, while the correlation with sucrose was unaffected $\left(R^{2}=0.10\right.$ vs. $R^{2}=$ 0.10). Even though the correlation improved for most biogenic tracers, it still can seem low. This is because the whole-year correlation is presented which also accounts for winter data where the concentration of both the biogenic tracers and $\mathrm{CM}_{\mathrm{Bio}(\mathrm{Mod})}$ is in general low, with high variability, resulting in very poor correlations $\left(\mathrm{R}^{2} \mathrm{MBTCA}=0.03 ; \mathrm{R}^{2}\right.$ Arabitol $=0.10 ; \mathrm{R}^{2}$ Sucrose $=0.01 ; \mathrm{R}^{2}$ Fructose $\left.=0.03\right)$. Seasonal correlation analysis of the biogenic tracers and $\mathrm{CM}_{\mathrm{Bio}(\mathrm{Mod})}$ show that the correlation is strong during spring for MBTCA $\left(\mathrm{R}^{2}=0.70, \mathrm{p}\right.$ $<0.01)$, arabitol $\left(\mathrm{R}^{2}=0.64, \mathrm{p}<0.01\right)$, sucrose $\left(\mathrm{R}^{2}=0.56, \mathrm{p}\right.$ $<0.01)$ and fructose $\left(\mathrm{R}^{2}=0.42, \mathrm{p}<0.01\right)$. The correlation during summer exhibit more straggling numbers where MBTCA still has a fairly high coefficient of determination to $\mathrm{CM}_{\mathrm{Bio}(\mathrm{Mod})}\left(\mathrm{R}^{2}=0.33, \mathrm{p}<0.01\right)$ while the three other biogenic tracers display very low coefficients $\left(\mathrm{R}^{2}\right.$ Arabitol $=$ $0.03, \mathrm{p}=0.034 ; \mathrm{R}^{2}$ Sucrose $=0.05, \mathrm{p}=0.25 ; \mathrm{R}^{2}$ Fructose $=0.05, \mathrm{p}$ $=0.25)$. It is possible that this discrepancy can be explained by continued photooxidation of $\alpha$-pinene, hence MBTCA formation, during summer while the activity in pollen and fungi spore production is reduced. Manninen et al. (2014) analyzed pollen and other BPOA from the Hyytiälä measurement station in Finland and found that the pollen concentration peaked in May while the other BPOA (including fungal spores) peaked in August or September. This finding is consistent with the temporal concentration variation for arabitol, sucrose and fructose as displayed in Fig. 1(c) and Table 1.

MBTCA and the other measured biogenic aerosol parameters presented here do unfortunately not act as a broad biogenic activity index. With the current selected chemical compounds, it is mainly possible to get an indication of the coniferous plant activity (i.e., large emitters of $\alpha$-pinene). Oxidation products from deciduous plant VOC emissions 


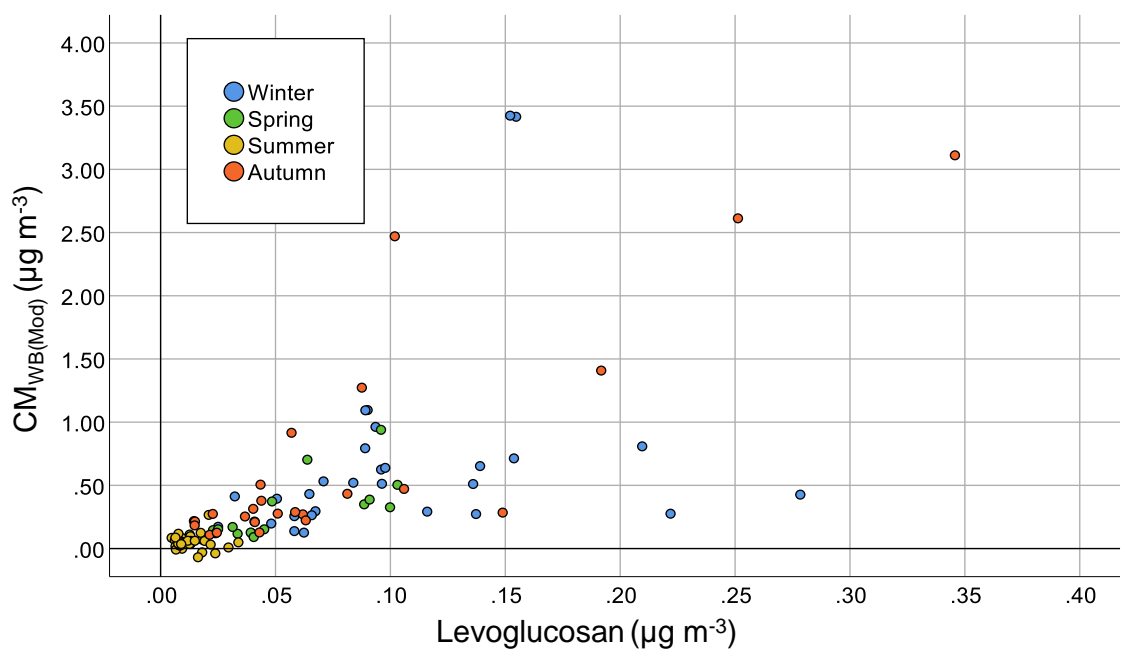

Fig. 3. Scatter plot displaying the relation between levoglucosan and $\mathrm{CM}_{\mathrm{WB}(\mathrm{Mod})} \mathrm{N}=106 ; \mathrm{R}^{2}=0.46$.

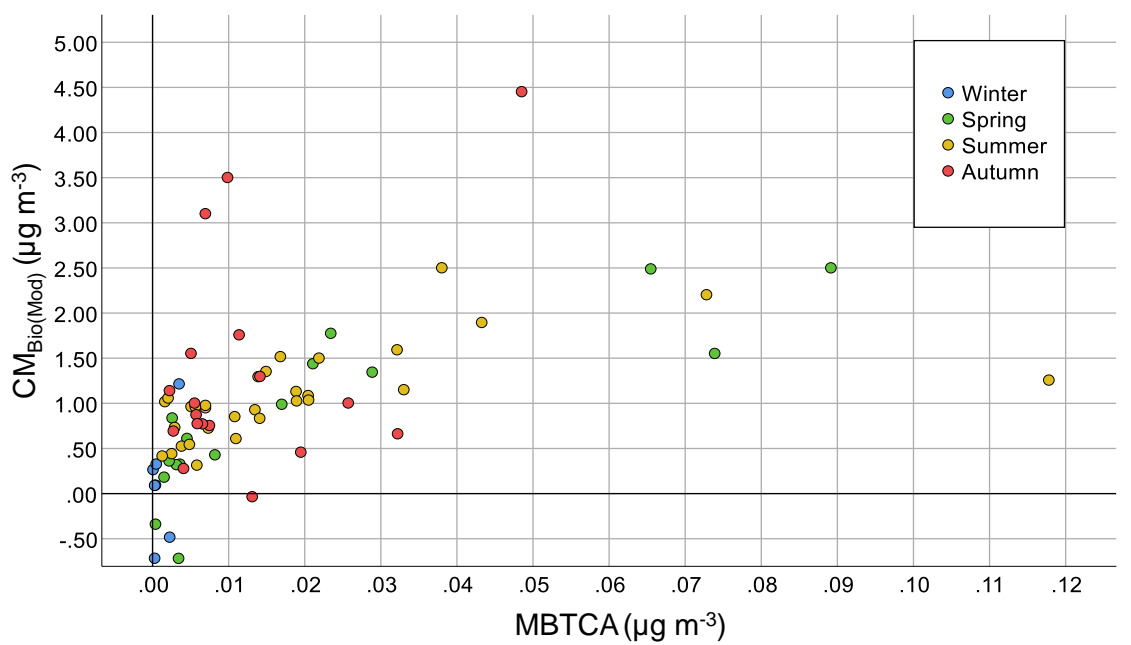

Fig. 4. Scatter plot displaying the relation between MBTCA and $\mathrm{CM}_{\mathrm{Bio}(\mathrm{Mod})}$. $\mathrm{N}=81 ; \mathrm{R}^{2}=0.27$.

(i.e., mainly isoprene) should be included in future studies when investigating the residual carbon of the aethalometer model.

All three sources displayed positive correlation between their calculated carbon mass concentrations and air masses from the southeastern sector $\left(\mathrm{R}^{2} \mathrm{CMFF}(\mathrm{Mod})=0.37, \mathrm{p}<0.01\right.$; $\left.\mathrm{R}^{2}{ }_{\mathrm{CMWB}(\operatorname{Mod})}=0.38, \mathrm{p}<0.01 ; \mathrm{R}^{2}{ }_{\mathrm{CMBio}(\text { Mod })}=0.14, \mathrm{p}<0.01\right)$. On the other hand, air masses from the northwestern sector (i.e., the North sea and Atlantic ocean) seemed to have a negative effect on the mass concentration from the three sources $\left(\mathrm{R}^{2}{ }_{\mathrm{CMFF}(\operatorname{Mod})}=0.17, \mathrm{p}<0.01 ; \mathrm{R}^{2}{ }_{\mathrm{CMWB}(\operatorname{Mod})}=0.12, \mathrm{p}\right.$ $\left.<0.01 ; \mathrm{R}^{2}{ }_{\mathrm{CMBio}(\mathrm{Mod})}=0.07, \mathrm{p}<0.01\right)$.

\section{Relationship between MBTCA and Aethalometer Model Parameters}

Surprisingly we found that the MBTCA concentration show a significant correlation with the aethalometer model light absorption for fossil fuel carbon ( $\mathrm{b}_{\mathrm{absFF}}(950 \mathrm{~nm})$ ) (Fig. 5, $\mathrm{R}^{2}=$ $0.20, \mathrm{p}<0.01)$. Although the whole year correlation is low, there is a clear covariance during spring $\left(\mathrm{R}^{2}=0.47, \mathrm{p}<0.01\right)$ and fall $\left(\mathrm{R}^{2}=0.58, \mathrm{p}<0.01\right)$. During the winter, the MBTCA concentrations are greatly suppressed and hence are unable

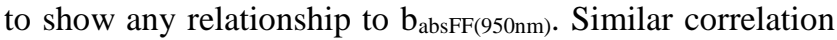
is lacking when studying the whole-year relationship between MBTCA and $b_{a b s W B(370 n m)}\left(R^{2}=0.01, p=0.39\right)$. Further, no significant relationships could be established between the

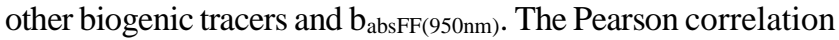
coefficient between MBTCA and the absorption coefficients derived from the seven wavelengths of the aethalometer show an increasing trend with higher wavelengths, and thus we find the highest correlation coefficient for $950 \mathrm{~nm}(0.23$, Fig. S3). This finding leads to several speculations. To the authors' knowledge, no studies exist on the investigation on the light absorption properties of the MBTCA molecule, hence one option is that MBTCA itself display light absorptive properties in the infrared region of the UV-IR spectra. Another option might be co-transport of biogenic aerosols containing MBTCA and aerosols with high absorption in $950 \mathrm{~nm}$ (i.e., soot) from similar geographical regions. As mentioned above, air masses from the southeastern sector are more polluted than air masses from other regions, this has been seen in previous publications from the Vavihill 


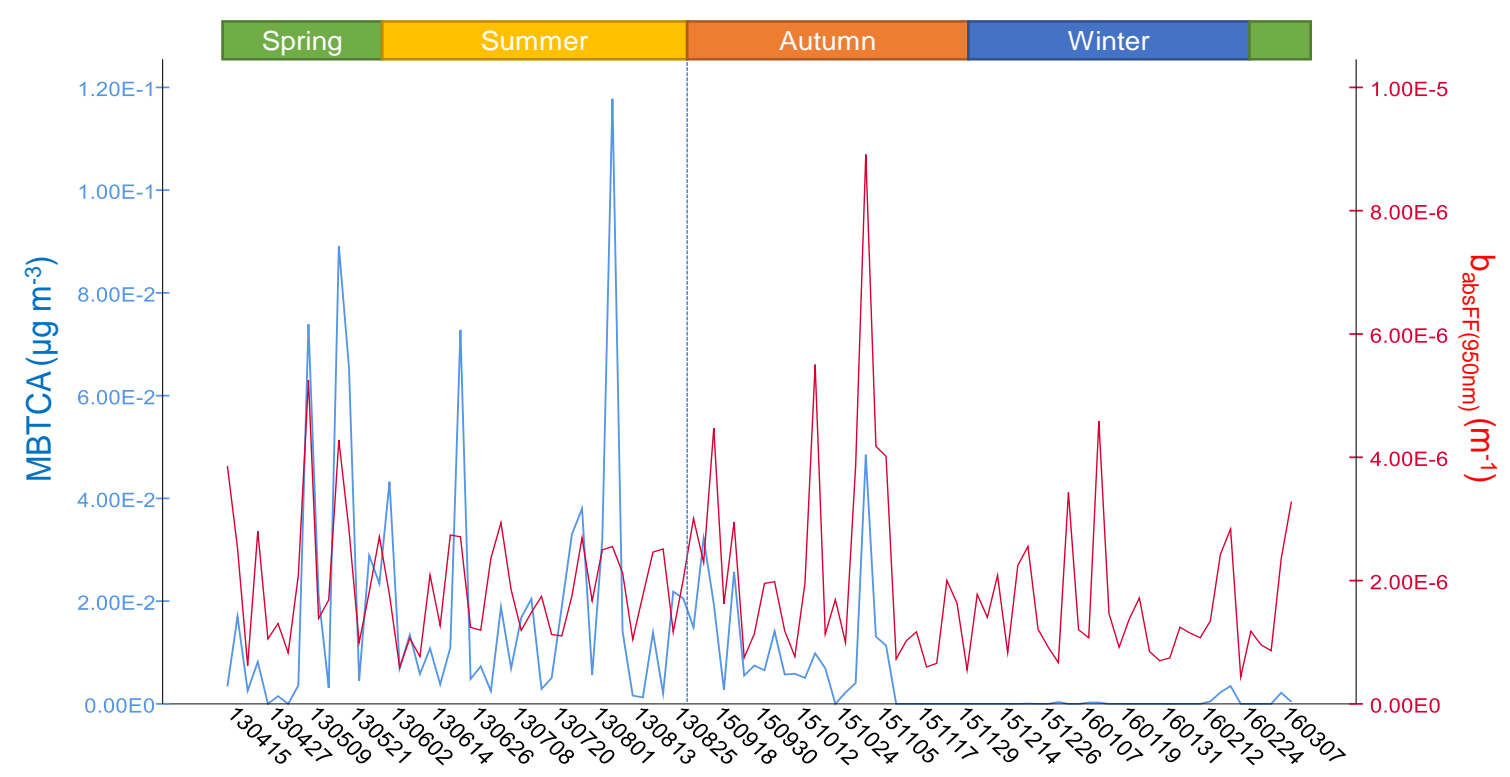

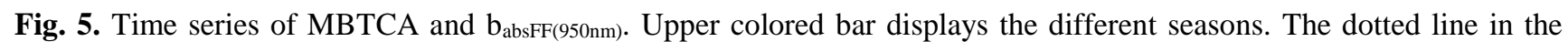
transition between summer and autumn displays the transition between the measurement period of 2013 and $2015-2016$. $\mathrm{N}_{\text {MBTCA }}=81, \mathrm{Nb}_{\text {absff( }(950 \mathrm{~nm})}=106 ; \mathrm{R}^{2}=0.20$.

measurement station (Kristensson et al., 2008; Martinsson et al., 2017b). Air masses from the southeastern sector of the Vavihill measurement station may originate from central Europe (eastern Germany, Czech Republic, Hungary, Slovakia and Poland) as well as major parts of eastern Europe (Ukraine, Belarus, Lithuania and Russia). We find large forests in parts of this sector, especially in Belarus, northern Ukraine northwestern Poland and Slovakia. With these facts in mind it is very possible that the co-variation between MBTCA and $b_{\text {absFF( } 950 \mathrm{~nm})}$ is explained by a co-transport rather than measurement detection of MBTCA in $b_{a b s F F(950 n m)}$. However, this speculation is contradicted by the low abundance of air masses from the southeastern sector which is only $13 \%$ for the whole measurement period. As stated above the correlation between $b_{a b s F(950 \mathrm{~nm})}$ and MBTCA was the highest during spring and fall, however the southeasterly air masses only occurred around $17 \%$ of the time during these seasons.

We investigated the light absorption of MBTCA through spectrophotometric analysis, the results are presented in Fig. 6. Regardless of the concentration, MBTCA showed distinct absorption peaks around 200-250 nm and 350-450 nm. In the wavelength region of interest for this discussion $(>800 \mathrm{~nm}$ ) there is a small increase in absorption. Unfortunately, due to the upper wavelength range of the instrument $(850 \mathrm{~nm})$ we are not able to study the absorption up to $950 \mathrm{~nm}$. Despite the absorption increase above $800 \mathrm{~nm}$ it is unlikely that this increase would explain any covariation between MBTCA and $b_{a b s(950 \mathrm{~nm})}$ for three reasons. First, the MBTCA mass used in the liquid solutions for the spectrophotometric analysis exceeds the ambient aerosol mass concentrations during summer (mean of $19 \mathrm{ng} \mathrm{m}^{-3}$ ) by $8-10$ orders of magnitude. As an example, a MBTCA solution of $10 \mathrm{mmol} \mathrm{L}^{-1}$ corresponds to approximately $0.05 \mathrm{~g}$ MBTCA in $25 \mathrm{~mL}$ ultrapure water. Hence it is likely that a realistic ambient aerosol MBTCA concentration used in spectrophotometric analysis would give results below the detection limit. Second, brown carbon $(\mathrm{BrC})$, a term for organic chemical compounds with enhanced light absorption in the UV-blue range that are produced in large quantities through biomass combustion, but can also be found in humic-like substances (HULIS) derived from biogenic oxidation products, is detectable in the aethalometer (Sandradewi et al., 2008b; Laskin et al., $2015)$ but has a light absorption per mass $\left(\alpha \rho^{-1}\right)$ that is $4-5$ orders of magnitude higher than the results from the spectrophotometric analysis (Chen and Bond, 2010). Third, if the experimental concentrations used in the spectrophotometric analysis would have had a significant impact in the aethalometer data, the $370 \mathrm{~nm}$ channel, i.e., $b_{\text {absWB(370nm), }}$ would also have correlated with MBTCA due to the absorption peak observed around $400 \mathrm{~nm}$ (Fig. 6).

Liu et al. (2016) presented a spectrum for mass absorption coefficients (MAC) for the MBTCA precursor $\alpha$-pinene. It was evident that the MAC value for $\alpha$-pinene in $370 \mathrm{~nm}$ is negligible while it is elevated at wavelengths above $600 \mathrm{~nm}$. Hence, it is possible that the observed correlation between MBTCA and $b_{a b s F(950 n m)}$ is explained by presence of the weak IR absorber, and MBTCA precursor, $\alpha$-pinene. Another option is that MBTCA are formed or co-emitted together with $\mathrm{BC}$, originating from fossil fuel or biomass combustion. However, this option is highly doubtful and emission of MBTCA from fossil fuel combustion has to the author's knowledge never been proved or seen earlier. Although, it should be noted that both MBTCA and $b_{\text {absFF(950nm) }}$ show increasing trends with a higher fraction of southeasterly air masses $\left(\mathrm{R}^{2}=0.09, \mathrm{p}=0.03\right.$ and $\mathrm{R}^{2}=0.38, \mathrm{p}<0.01$ respectively), a geographic sector that has been shown to contribute with anthropogenic air pollutants (Kristensson et al., 2008; Martinsson et al., 2017b). The three remaining air mass sectors (NE, NW, SW) contribute with declining 


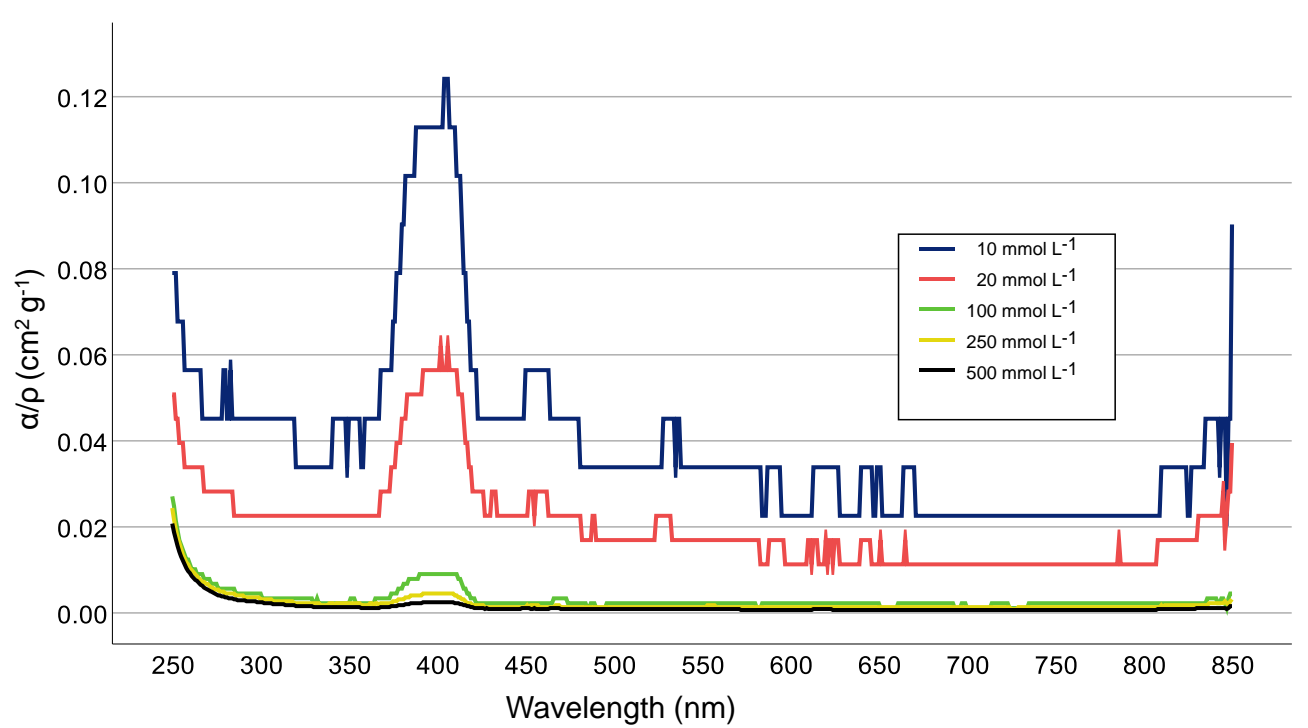

Fig. 6. Absorption per mass $(\alpha / \rho)$ for MBTCA. The wavelength section between $200-249 \mathrm{~nm}$ has been removed due to very high $\alpha / \rho$ values $(>6)$.

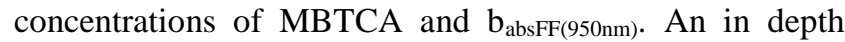
investigation of the causes of this finding goes beyond the scope of this paper, however the suspicion from Martinsson et al. (2017b) that biogenic carbon might interfere and possibly obstruct the $\mathrm{CM}_{\mathrm{FF}}$ quantification in the aethalometer model is still unclear and demands further investigation. However, in this study the MBTCA concentrations was very low and in many cases below detection limit during winter, which is the period used for deriving the $\mathrm{C}$ parameters in the aethalometer model. Hence, in this study the $\mathrm{C}$ parameters should be spared the interference of the possible IR absorbing MBTCA molecule.

\section{CONCLUSIONS}

In this study, we demonstrated that four common biogenic tracers showed positive correlation with the aethalometer model residual carbon, apportioned as biogenic carbon, $\mathrm{CM}_{\mathrm{Bio}}$. We also illustrated the need and performance to modify and optimize the $\mathrm{C}$ parameters, in this case the $\mathrm{C}_{1}$ parameter. It should be noted that such a modification demands a thorough comparison between the aethalometer model output parameters and a tracer-based source apportionment that includes radiocarbon, levoglucosan and biogenic tracer measurement. In this study we used radiocarbon and levoglucosan source apportionment data generated from a previous study conducted at the same measurement station. To conclude, several years of measurements may be needed in order to establish stable $\mathrm{C}$ parameters for a particular measurement station, an aethalometer instrument and a thermo-optical instrument.

Surprisingly, we also found that MBTCA displayed a positive correlation with the derived absorption coefficients from fossil fuel carbonaceous aerosol, stressing the suspicion that biogenic aerosol might be falsely apportioned to this fraction. Hence, future studies should be directed towards experimental investigations with the aim of studying the light absorption properties of artificially produced biogenic secondary organic aerosol. The experimental investigation should be parallel to further ambient aerosol studies utilizing high time resolved instrumentation such as the aerosol mass spectrometer as a complement to wet chemistry filter analysis.

\section{ACKNOWLEDGEMENTS}

This work was supported by the Swedish Research Council FORMAS (project 2011-743). An acknowledgement is given to Dr. Daniel Molins Delgado who supported with the spectrophotometric instrumentation.

\section{SUPPLEMENTARY MATERIAL}

Supplementary data associated with this article can be found in the online version at https://doi.org/10.4209/aaqr.2 020.01 .0035

\section{REFERENCES}

Andersson-Sköld, Y. and Simpson, D. (2001). Secondary organic aerosol formation in northern Europe: A model study. J. Geophys. Res. 106: 7357-7374. https://doi.org/ 10.1029/2000JD900656

Barregard, L., Sällsten, G., Gustafson, P., Johansson, L., Andersson, L. and Stigendal, L. (2006). Experimental exposure to wood smoke particles in healthy humans: Effects on markers of inflammation and coagulation. Epidemiology 17: S160-S161. https://doi.org/10.1080/08 958370600685798

Bauer, H., Claeys, M., Vermeylen, R., Schueller, E., Weinke, G., Berger, A. and Puxbaum, H. (2008). Arabitol and mannitol as tracers for the quantification of airborne fungal spores. Atmos. Environ. 42: 588-593. https://doi.org/ 10.1016/j.atmosenv.2007.10.013

Bolling, A.K., Pagels, J., Yttri, K.E., Barregard, L., Sällsten, G., Schwarze, P.E. and Boman, C. (2009). Health effects 
of residential wood smoke particles: The importance of combustion conditions and physicochemical particle properties. Part. Fibre Toxicol. 6: 29. https://doi.org/10.1 186/1743-8977-6-29

Bond, T.C. and Bergstrom, R.W. (2006). Light absorption by carbonaceous particles: An investigative review. Aerosol Sci. Technol. 40: 27-67. https://doi.org/10.1080/ 02786820500421521

Bond, T.C., Doherty, S.J., Fahey, D.W., Forster, P.M., Berntsen, T., DeAngelo, B.J., Flanner, M.G., Ghan, S., Karcher, B., Koch, D., Kinne, S., Kondo, Y., Quinn, P.K., Sarofim, M.C., Schultz, M.G., Schulz, M., Venkataraman, C., Zhang, H., Zhang, S., Bellouin, N., Guttikunda, S.K., Hopke, P.K., Jacobson, M.Z., Kaiser, J.W., Klimont, Z., Lohmann, U., Schwarz, J.P., Shindell, D., Storelvmo, T., Warren, S.G. and Zender, C.S. (2013). Bounding the role of black carbon in the climate system: A scientific assessment. J. Geophys. Res. 118: 5380-5552. https://doi.org/10.1002/jgrd.50171

Burshtein, N., Lang-Yona, N. and Rudich, Y. (2011). Ergosterol, arabitol and mannitol as tracers for biogenic aerosols in the eastern Mediterranean. Atmos. Chem. Phys. 11: 829-839. https://doi.org/10.5194/acp-11-829-2011

Caseiro, A., Marr, I.L., Claeys, M., Kasper-Giebl, A., Puxbaum, H. and Pio, C.A. (2007). Determination of Saccharides in atmospheric aerosol using anion-exchange high-performance liquid chromatography and pulsedamperometric detection. J. Chromatogr. A 1171: 37-45. https://doi.org/10.1016/j.chroma.2007.09.038

Cavalli, F., Alastuey, A., Areskoug, H., Ceburnis, D., Cech, J., Genberg, J., Harrison, R.M., Jaffrezo, J.L., Kiss, G., Laj, P., Mihalopoulos, N., Perez, N., Quincey, P., Schwarz, J., Sellegri, K., Spindler, G., Swietlicki, E., Theodosi, C., Yttri, K.E., Aas, W. and Putaud, J.P. (2016). A European aerosol phenomenology -4: Harmonized concentrations of carbonaceous aerosol at 10 regional background sites across Europe. Atmos. Environ. 144: 133-145. https://doi.org/10.1016/j.atmosenv.2016.07.050

Cavalli, F., Viana, M., Yttri, K.E., Genberg, J. and Putaud, J.P. (2010). Toward a standardised thermal-optical protocol for measuring atmospheric organic and elemental carbon: The EUSAAR protocol. Atmos. Meas. Tech. 3: 79-89. https://doi.org/10.5194/amt-3-79-2010

Chen, Y. and Bond, T.C. (2010). Light Absorption by Organic Carbon from Wood Combustion. Atmos. Chem. Phys. 10: 1773-1787. https://doi.org/10.5194/acp-101773-2010

Cowie, G.L. and Hedges, J.I. (1984). Carbohydrate sources in a coastal marine-environment. Geochim. Cosmochim. Acta 48: 2075-2087.

Donahue, N.M., Ortega, I.K., Chuang, W., Riipinen, I., Riccobono, F., Schobesberger, S., Dommen, J., Baltensperger, U., Kulmala, M., Worsnop, D.R. and Vehkamaki, H. (2013). How do organic vapors contribute to new-particle formation? Faraday Discuss. 165: 91104. https://doi.org/10.1039/C3FD00046J

Draxier, R.R. and Hess, G.D. (1998). An overview of the HYSPLIT_4 modelling system for trajectories, dispersion, and deposition. Aust. Meteorol. Mag. 47: 295-308.
Drinovec, L., Mocnik, G., Zotter, P., Prevot, A.S.H., Ruckstuhl, C., Coz, E., Rupakheti, M., Sciare, J., Muller, T., Wiedensohler, A. and Hansen, A.D.A. (2015). The "dual-spot" Aethalometer: An improved measurement of aerosol black carbon with real-time loading compensation. Atmos. Meas. Tech. 8: 1965-1979. https://doi.org/10.519 4/amt-8-1965-2015

Fu, P.Q., Kawamura, K., Chen, J. and Barrie, L.A. (2009). Isoprene, monoterpene, and sesquiterpene oxidation products in the high Arctic aerosols during late winter to early summer. Environ. Sci. Technol. 43: 4022-4028. https://doi.org/10.1021/es803669a

Fuzzi, S., Baltensperger, U., Carslaw, K., Decesari, S., van Der Gon, H.D., Facchini, M.C., Fowler, D., Koren, I., Langford, B., Lohmann, U., Nemitz, E., Pandis, S., Riipinen, I., Rudich, Y., Schaap, M., Slowik, J.G., Spracklen, D.V., Vignati, E., Wild, M., Williams, M. and Gilardoni, S. (2015). Particulate matter, air quality and climate: Lessons learned and future needs. Atmos. Chem. Phys. 15: 8217-8299. https://doi.org/10.5194/acp-15-8217-2015

Gabric, A., Gregg, W., Najjar, R., Erickson, D. and Matrai, P. (2001). Modeling the biochemical cycle of dimethylsulfide in the upper ocean: A review. Chemosphere - Global Change Sci. 3: 377-392. https://doi.org/10.1016/S1465-9972(01)00018-6

Gao, S., Surratt, J.D., Knipping, E.M., Edgerton, E.S., Shahgholi, M. and Seinfeld, J.H. (2006). Characterization of polar organic components in fine aerosols in the southeastern United States: Identity, origin, and evolution. $J$. Geophys. Res. 111: D14314. https://doi.org/10.1029/200 5JD006601

Gelencser, A., May, B., Simpson, D., Sanchez-Ochoa, A., Kasper-Giebl, A., Puxbaum, H., Caseiro, A., Pio, C. and Legrand, M. (2007). Source apportionment of $\mathrm{PM}_{2.5}$ organic aerosol over Europe: Primary/secondary, natural/anthropogenic, and fossil/biogenic origin. $J$. Geophys. Res. 112: D23S04. https://doi.org/10.1029/200 6JD008094

Genberg, J., Hyder, M., Stenström, K., Bergström, R., Simpson, D., Fors, E.O., Jönsson, J.A. and Swietlicki, E. (2011). Source apportionment of carbonaceous aerosol in southern Sweden. Atmos. Chem. Phys. 11: 11387-11400. https://doi.org/10.5194/acp-11-11387-2011

Glasius, M. and Goldstein, A.H. (2016). Recent discoveries and future challenges in atmospheric organic chemistry. Environ. Sci. Technol. 50: 2754-2764. https://doi.org/10. 1021/acs.est.5b05105

Guenther, A.B., Zimmerman, P.R., Harley, P.C., Monson, R.K. and Fall, R. (1993). Isoprene and monoterpene emission rate variability: Model evaluations and sensitivity analyses. J. Geophys. Res. 98: 12609-12617. https://doi.org/10.1029/93JD00527

Guenther, A., Hewitt, C.N., Erickson, D., Fall, R., Geron, C., Graedel, T., Harley, P., Klinger, L., Lerdau, M., Mckay, W.A., Pierce, T., Scholes, B., Steinbrecher, R., Tallamraju, R., Taylor, J. and Zimmerman, P. (1995). A global-model of natural volatile organic-compound emissions. $J$. Geophys. Res. 100: 8873-8892. https://doi.org/10.1029/9 4JD02950 
Guenther, A.B., Jiang, X., Heald, C.L., Sakulyanontvittaya, T., Duhl, T., Emmons, L.K. and Wang, X. (2012). The Model of Emissions of Gases and Aerosols from Nature version 2.1 (MEGAN2.1): An extended and updated framework for modeling biogenic emissions. Geosci. Model Dev. 5: 1471-1492. https://doi.org/10.5194/gmd5-1471-2012

Hakola, H., Hellen, H., Hemmila, M., Rinne, J. and Kulmala, M. (2012). In situ measurements of volatile organic compounds in a boreal forest. Atmos. Chem. Phys. 12: 11665-11678. https://doi.org/10.5194/acp-12-116652012

Hakola, H., Tarvainen, V., Laurila, T., Hiltunen, V., Hellen, H. and Keronen, P. (2003). Seasonal variation of VOC concentrations above a boreal coniferous forest. Atmos. Environ. 37: 1623-1634. https://doi.org/10.1016/S13522310(03)00014-1

Henry, K.M. and Donahue, N.M. (2012). Photochemical aging of $\alpha$-pinene secondary organic aerosol: Effects of $\mathrm{OH}$ radical sources and photolysis. J. Phys. Chem. A 116: 5932-5940. https://doi.org/10.1021/jp210288s

IPCC (2013). Summary for Policymakers. In Climate Change 2013: The Physical Science Basis. Contribution of Working Group I to the Fifth Assessment Report of the Intergovernmental Panel on Climate Change, Stocker, T.F., Qin, D., Plattner, G.K., Tignor, M., Allen, S.K., Boschung, J., Nauels, A., Xia, Y., Bex, V. and Midgley, P.M. (Eds.), Cambridge University Press, Cambridge, United Kingdom and New York, NY, USA.

Janssen, N.A.H., Hoek, G., Simic-Lawson, M., Fischer, P., van Bree, L., ten Brink, H., Keuken, M., Atkinson, R.W., Anderson, H.R., Brunekreef, B. and Cassee, F.R. (2011). Black carbon as an additional indicator of the adverse health effects of airborne particles compared with $\mathrm{PM}_{10}$ and $\mathrm{PM}_{2.5}$. Environ. Health Perspect. 119: 1691-1699. https://doi.org/10.1289/ehp.1003369

Jaoui, M. and Kamens, R.M. (2002). Mass balance of gaseous and particulate products analysis from $\alpha$ pinene/ $\mathrm{NO}_{\mathrm{x}} /$ air in the presence of natural sunlight. $J$. Geophys. Res. 106: 12541-12558. https://doi.org/10.102 9/2001JD900005

Kanakidou, M., Seinfeld, J.H., Pandis, S.N., Barnes, I., Dentener, F.J., Facchini, M.C., Van Dingenen, R., Ervens, B., Nenes, A., Nielsen, C.J., Swietlicki, E., Putaud, J.P., Balkanski, Y., Fuzzi, S., Horth, J., Moortgat, G.K., Winterhalter, R., Myhre, C.E.L., Tsigaridis, K., Vignati, E., Stephanou, E.G. and Wilson, J. (2005). Organic aerosol and global climate modelling: A review. Atmos. Chem. Phys. 5: 1053-1123. https://doi.org/10.5194/acp5-1053-2005

Kostenidou, E., Karnezi, E., Kolodziejczyk, A., Szmigielski, R. and Pandis, S.N. (2018). Physical and chemical properties of 3-methyl-1,2,3-butanetricarboxylic acid (MBTCA) aerosol. Environ. Sci. Technol. 52: 11501155. https://doi.org/10.1021/acs.est.7b04348

Kourtchev, I., Ruuskanen, T.M., Keronen, P., Sogacheva, L., Dal Maso, M., Reissell, A., Chi, X., Vermeylen, R., Kulmala, M., Maenhaut, W. and Claeys, M. (2008a). Determination of isoprene and $\alpha$-/ $\beta$-pinene oxidation products in boreal forest aerosols from Hyytiälä, Finland: diel variations and possible link with particle formation events. Plant Biol. 10: 138-149. https://doi.org/10.1055/s $-2007-964945$

Kourtchev, I., Warnke, J., Maenhaut, W., Hoffmann, T. and Claeys, M. (2008b). Polar organic marker compounds in $\mathrm{PM}_{2.5}$ aerosol from a mixed forest site in western Germany. Chemosphere 73: 1308-1314. https://doi.org/1 0.1016/j.chemosphere.2008.07.011

Kourtchev, I., Copolovici, L., Claeys, M. and Maenhaut, W. (2009). Characterization of atmospheric aerosols at a forested site in central Europe. Environ. Sci. Technol. 43: 4665-4671. https://doi.org/10.1021/es803055w

Kristensen, K. and Glasius, M. (2011). Organosulfates and oxidation products from biogenic hydrocarbons in fine aerosols from a forest in North West Europe during spring. Atmos. Environ. 45: 4546-4556. https://doi.org/10.1016/ j.atmosenv.2011.05.063

Kristensson, A., Dal Maso, M., Swietlicki, E., Hussein, T., Zhou, J., Kerminen, V.M. and Kulmala, M. (2008). Characterization of New particle formation events at a background site in southern Sweden: Relation to air mass history. Tellus B 60: 330-344. https://doi.org/10.1111/j.1 600-0889.2008.00345.x

Kubatova, A., Vermeylen, R., Claeys, M., Cafmeyer, J., Maenhaut, W., Roberts, G. and Artaxo, P. (2000). Carbonaceous aerosol characterization in the Amazon basin, Brazil: Novel dicarboxylic acids and related compounds. Atmos. Environ. 34: 5037-5051. https://doi.org/10.1016/S1352-2310(00)00320-4

Kubatova, A., Vermeylen, R., Claeys, M., Cafmeyer, J. and Maenhaut, W. (2002). Organic compounds in urban aerosols from Gent, Belgium: Characterization, sources, and seasonal differences. J. Geophys. Res. 107: 8343. https://doi.org/10.1029/2001JD000556

Laothawornkitkul, J., Taylor, J.E., Paul, N.D. and Hewitt, C.N. (2009). Biogenic volatile organic compounds in the Earth system. New Phytol. 183: 27-51. https://doi.org/10. 1111/j.1469-8137.2009.02859.x

Larsen, B.R., Di Bella, D., Glasius, M., Winterhalter, R., Jensen, N.R. and Hjorth, J. (2001). Gas-phase ozone oxidation of monoterpenes: Gaseous and particulate products. J. Atmos. Chem. 38: 231-276. https://doi.org/1 0.1023/A:1006487530903

Laskin, A., Laskin, J. and Nizkorodov, S.A. (2015). Chemistry of atmospheric brown carbon. Chem. Rev. 115: 4335-4382. https://doi.org/10.1021/cr5006167

Laskin, J., Laskin, A., Nizkorodov, S.A., Roach, P., Eckert, P., Gilles, M.K., Wang, B.B., Lee, H.J. and Hu, Q.C. (2014). Molecular selectivity of brown carbon chromophores. Environ. Sci. Technol. 48: 12047-12055. https://doi.org/10.1021/acs.est.6b03024

Lee, A., Goldstein, A.H., Keywood, M.D., Gao, S., Varutbangkul, V., Bahreini, R., Ng, N.L., Flagan, R.C. and Seinfeld, J.H. (2006). Gas-phase products and secondary aerosol yields from the ozonolysis of ten different terpenes. J. Geophys. Res. 111: D07302. https://doi.org/1 0.1029/2005JD006437

Lewandowski, M., Jaoui, M., Kleindienst, T.E., Offenberg, 
J.H. and Edney, E.O. (2007). Composition of $\mathrm{PM}_{2.5}$ during the summer of 2003 in Research Triangle Park, North Carolina. Atmos. Environ. 41: 4073-4083. https://doi.org/10.1016/j.atmosenv.2007.01.012

Liousse, C., Penner, J.E., Chuang, C., Walton, J.J., Eddleman, H. and Cachier, H. (1996). A global three-dimensional model study of carbonaceous aerosols. J. Geophys. Res. 101: 19411-19432. https://doi.org/10.1029/95JD03426

Liu, J.M., Lin, P., Laskin, A., Laskin, J., Kathmann, S.M., Wise, M., Caylor, R., Imholt, F., Selimovic, V. and Shilling, J.E. (2016). Optical properties and aging of light-absorbing secondary organic aerosol. Atmos. Chem. Phys. 16: 12815-12827. https://doi.org/10.5194/acp-1612815-2016

Maenhaut, W., Chi, X.G., Wang, W., Cafmeyer, J., Yasmeen, F., Vermeylen, R., Szmigielska, K., Janssens, I.A. and Claeys, M. (2017). Contribution from selected organic species to $\mathrm{PM}_{2.5}$ aerosol during a summer field campaign at K-Puszta, Hungary. Atmosphere 8: 221. https://doi.org/10.3390/atmos8110221

Manninen, H.E., Back, J., Sihto-Nissila, S.L., Huffman, J.A., Pessi, A.M., Hiltunen, V., Aalto, P.P., Hidalgo, P.J., Hari, P., Saarto, A., Kulmala, M. and Petaja, T. (2014). Patterns in airborne pollen and other primary biological aerosol particles (PBAP), and their contribution to aerosol mass and number in a boreal forest. Boreal Environ. Res. 19: 383-405.

Martinsson, J., Andersson, A., Sporre, M.K., Friberg, J., Kristensson, A., Swietlicki, E., Olsson, P.A. and Stenström, K.E. (2017a). Evaluation of $\delta^{13} \mathrm{C}$ in carbonaceous aerosol source apportionment at a rural measurement site. Aerosol Air Qual Res 17: 2081-2094. https://doi.org/10.4209/aaq r.2016.09.0392

Martinsson, J., Azeem, H.A., Sporre, M.K., Bergstrom, R., Ahlberg, E., Östrom, E., Kristensson, A., Swietlicki, E. and Stenström, K.E. (2017b). Carbonaceous aerosol source apportionment using the Aethalometer model evaluation by radiocarbon and levoglucosan analysis at a rural background site in southern Sweden. Atmos. Chem. Phys. 17: 4265-4281. https://doi.org/10.5194/acp-174265-2017

Martinsson, J., Monteil, G., Sporre, M.K., Hansen, A.M.K., Kristensson, A., Stenström, K.E., Swietlicki, E. and Glasius, M. (2017c). Exploring sources of biogenic secondary organic aerosol compounds using chemical analysis and the FLEXPART model. Atmos. Chem. Phys. 17: 11025-11040. https://doi.org/10.5194/acp-17-110252017

Monson, R.K., Jones, R.T., Rosenstiel, T.N. and Schnitzler, J.P. (2013). Why only some plants emit isoprene. Plant Cell Environ. 36: 503-516. https://doi.org/10.1111/pce.1 2015

Muller, L., Reinnig, M.C., Naumann, K.H., Saathoff, H., Mentel, T.F., Donahue, N.M. and Hoffmann, T. (2012). Formation of 3-methyl-1,2,3-butanetricarboxylic acid via gas phase oxidation of pinonic acid - a mass spectrometric study of SOA aging. Atmos. Chem. Phys. 12: 1483-1496. https://doi.org/10.5194/acp-12-1483-2012

Naeher, L.P., Brauer, M., Lipsett, M., Zelikoff, J.T.,
Simpson, C.D., Koenig, J.Q. and Smith, K.R. (2007). Woodsmoke health effects: A review. Inhalation Toxicol. 19: 67-106. https://doi.org/10.1080/08958370600985875 Nakayama, T., Matsumi, Y., Sato, K., Imamura, T., Yamazaki, A. and Uchiyama, A. (2010). Laboratory studies on optical properties of secondary organic aerosols generated during the photooxidation of toluene and the ozonolysis of a-pinene. J. Geophys. Res. 115: D24204. https://doi.org/10.1029/2010JD014387

Penuelas, J. and Llusia, J. (2003). BVOCs: plant defense against climate warming? Trends Plant Sci. 8: 105-109. https://doi.org/10.1016/S1360-1385(03)00008-6

Pietrogrande, M.C., Bacco, D., Visentin, M., Ferrari, S. and Poluzzi, V. (2014). Polar organic marker compounds in atmospheric aerosol in the Po Valley during the Supersito campaigns - Part 1: Low molecular weight carboxylic acids in cold seasons. Atmos. Environ. 86: 164-175. https://doi.org/10.1016/j.atmosenv.2013.12.022

Putaud, J.P., Van Dingenen, R., Alastuey, A., Bauer, H., Birmili, W., Cyrys, J., Flentje, H., Fuzzi, S., Gehrig, R., Hansson, H.C., Harrison, R.M., Herrmann, H., Hitzenberger, R., Huglin, C., Jones, A.M., Kasper-Giebl, A., Kiss, G., Kousa, A., Kuhlbusch, T.A.J., Loschau, G., Maenhaut, W., Molnar, A., Moreno, T., Pekkanen, J., Perrino, C., Pitz, M., Puxbaum, H., Querol, X., Rodriguez, S., Salma, I., Schwarz, J., Smolik, J., Schneider, J., Spindler, G., ten Brink, H., Tursic, J., Viana, M., Wiedensohler, A. and Raes, F. (2010). A European aerosol phenomenology - 3: Physical and chemical characteristics of particulate matter from 60 rural, urban, and kerbside sites across Europe. Atmos. Environ. 44: 1308-1320. https://doi.org/1 0.1016/j.atmosenv.2009.12.011

Räisänen, T., Ryyppö, A. and Kellomäki, S. (2008). Effects of elevated $\mathrm{CO}_{2}$ and temperature on monoterpene emission of Scots pine (Pinus sylvestris L.) Atmos. Environ. 42: 4160-4171. https://doi.org/10.1016/j.atmosenv.2008.01. 023

Sandradewi, J., Prevot, A.S.H., Szidat, S., Perron, N., Alfarra, M.R., Lanz, V.A., Weingartner, E. and Baltensperger, U. (2008a). Using aerosol light absorption measurements for the quantitative determination of wood burning and traffic emission contributions to particulate matter. Environ. Sci. Technol. 42: 3316-3323. https://doi.org/10.1021/es70225 $3 \mathrm{~m}$

Sandradewi, J., Prevot, A.S.H., Weingartner, E., Schmidhauser, R., Gysel, M. and Baltensperger, U. (2008b). A A study of wood burning and traffic aerosols in an Alpine valley using a multi-wavelength Aethalometer. Atmos. Environ. 42: 101-112. https://doi.org/10.1016/j.atmosenv.2007.0 9.034

Sehlstedt, M., Dove, R., Boman, C., Pagels, J., Swietlicki, E., Löndahl, J., Westerholm, R., Bosson, J., Barath, S., Behndig, A.F., Pourazar, J., Sandström, T., Mudway, I.S. and Blomberg, A. (2010). Antioxidant airway responses following experimental exposure to wood smoke in man. Part. Fibre Toxicol. 7: 21. https://doi.org/10.1186/17438977-7-21

Sharkey, T.D., Wiberley, A.E. and Donohue, A.R. (2008). Isoprene emission from plants: Why and how. Ann. Bot. 
101: 5-18. https://doi.org/10.1093/aob/mcm240

Siljamo, P., Sofiev, M., Severova, E., Ranta, H., Kukkonen, J., Polevova, S., Kubin, E. and Minin, A. (2008). Sources, impact and exchange of early-spring birch pollen in the Moscow region and Finland. Aerobiologia 24: 211-230. https://doi.org/10.1007/s10453-008-9100-8

Speranza, A., Calzoni, G.L. and Pacini, E. (1997). Occurrence of mono- or disaccharides and polysaccharide reserves in mature pollen grains. Sex. Plant Reprod. 10: 110-115. https://doi.org/10.1007/s004970050076

Sporre, M.K., Blichner, S.M., Karset, I.H.H., Makkonen, R. and Berntsen, T.K. (2019). BVOC-aerosol-climate feedbacks investigated using NorESM. Atmos. Chem. Phys. 19: 4763-4782. https://doi.org/10.5194/acp-194763-2019

Stein, A.F., Draxler, R.R., Rolph, G.D., Stunder, B.J.B., Cohen, M.D. and Ngan, F. (2015). NOAA's HYSPLIT atmospheric transport and dispersion modeling system. Bull. Amer. Meteor. Soc. 96: 2059-2077. https://doi.org/ 10.1175/BAMS-D-14-00110.1

Steinke, M., Hodapp, B., Subhan, R., Bell, T.G. and MartinCreuzburg, D. (2018). Flux of the biogenic volatiles isoprene and dimethyl sulfide from an oligotrophic lake. Sci. Rep. 8: 630. https://doi.org/10.1038/s41598-01718923-5

Szmigielski, R., Surratt, J.D., Gomez-Gonzalez, Y., Van der Veken, P., Kourtchev, I., Vermeylen, R., Blockhuys, F., Jaoui, M., Kleindienst, T.E., Lewandowski, M., Offenberg, J.H., Edney, E.O., Seinfeld, J.H., Maenhaut, W. and Claeys, M. (2007). 3-methyl-1,2,3-butanetricarboxylic acid: An atmospheric tracer for terpene secondary organic aerosol. Geophys Res Lett 34: L24811. https://doi.org/10. 1029/2007GL031338

Verma, S.K., Kawamura, K., Chen, J. and Fu, P.Q. (2018). Thirteen years of observations on primary sugars and sugar alcohols over remote Chichijima Island in the western North Pacific. Atmos. Chem. Phys. 18: 81-101. https://doi.org/10.5194/acp-18-81-2018

Vogel, A.L., Äijälä, M., Corrigan, A.L., Junninen, H., Ehn, M., Petäjä, T., Worsnop, D.R., Kulmala, M., Russell, L.M., Williams, J. and Hoffmann, T. (2013). In situ submicron organic aerosol characterization at a boreal forest research station during HUMPPA-COPEC 2010 using soft and hard ionization mass spectrometry. Atmos. Chem. Phys. 13: 10933-10950. https://doi.org/10.5194/a cp-13-10933-2013

Weingartner, E., Saathoff, H., Schnaiter, M., Streit, N., Bitnar, B. and Baltensperger, U. (2003). Absorption of light by soot particles: determination of the absorption coefficient by means of aethalometers. J. Aerosol Sci. 34: 1445-1463. https://doi.org/10.1016/S0021-8502(03)003 59-8

Yasmeen, F., Szmigielski, R., Vermeylen, R., GomezGonzalez, Y., Surratt, J.D., Chan, A.W.H., Seinfeld, J.H., Maenhaut, W. and Claeys, M. (2011). Mass spectrometric characterization of isomeric terpenoic acids from the oxidation of $\alpha$-pinene, $\beta$-pinene, d-limonene, and $\Delta 3$ carene in fine forest aerosol. J. Mass Spectrom. 46: 425442. https://doi.org/10.1002/jms.1911

Yli-Panula, E., Fekedulegn, D.B., Green, B.J. and Ranta, H. (2009). Analysis of airborne betula pollen in Finland; a 31-year perspective. Int. J. Environ. Res. Public Health 6: 1706-1723. https://doi.org/10.3390/ijerph6061706

Yttri, K.E., Dye, C. and Kiss, G. (2007). Ambient aerosol concentrations of sugars and sugar-alcohols at four different sites in Norway. Atmos. Chem. Phys. 7: 42674279. https://doi.org/10.5194/acp-7-4267-2007

Yttri, K.E., Simpson, D., Nojgaard, J.K., Kristensen, K., Genberg, J., Stenström, K., Swietlicki, E., Hillamo, R., Aurela, M., Bauer, H., Offenberg, J.H., Jaoui, M., Dye, C., Eckhardt, S., Burkhart, J.F., Stohl, A. and Glasius, M. (2011). Source apportionment of the summer time carbonaceous aerosol at Nordic rural background sites. Atmos. Chem. Phys. 11: 13339-13357. https://doi.org/10. 5194/acp-11-13339-2011

Zhang, Y.Y., Muller, L., Winterhalter, R., Moortgat, G.K., Hoffmann, T. and Poschl, U. (2010). Seasonal cycle and temperature dependence of pinene oxidation products, dicarboxylic acids and nitrophenols in fine and coarse air particulate matter. Atmos. Chem. Phys. 10: 7859-7873. https://doi.org/10.5194/acp-10-7859-2010

Received for review, February 19, 2020 Revised, September 7, 2020 Accepted, September 8, 2020 